Florida International University FIU Digital Commons

4-17-2003

\title{
A conceptual framework for understanding contemporary child slavery
}

Cecilia Nana Derby

Florida International University

DOI: $10.25148 /$ etd.FI14062244

Follow this and additional works at: https://digitalcommons.fiu.edu/etd

Part of the Sociology Commons

\section{Recommended Citation}

Derby, Cecilia Nana, "A conceptual framework for understanding contemporary child slavery" (2003). FIU Electronic Theses and Dissertations. 2774.

https://digitalcommons.fiu.edu/etd/2774

This work is brought to you for free and open access by the University Graduate School at FIU Digital Commons. It has been accepted for inclusion in FIU Electronic Theses and Dissertations by an authorized administrator of FIU Digital Commons. For more information, please contact dcc@fiu.edu. 
FLORIDA INTENATIONAL UNIVERSITY

Miami, Florida

\section{A CONCEPTUAL FRAMEWORK FOR UNDERSTANDING CONTEMPORARY CHILD SLAVERY}

A thesis submitted in partial fulfillment of the requirements for the degree of

MASTER OF ARTS

in

COMPARATIVE SOCIOLOGY

by

Cecilia Nana Derby 
To: Dean Arthur W. Herriott

College of Arts and Sciences

This thesis, written by Cecilia Nana Derby, and entitled A Conceptual Framework for Understanding Contemporary Child Slavery, having been approved in respect to style and intellectual content, is referred to you for judgment.

We have read this thesis and recommend that it be approved.

Barry Levine

Betty Hearn Morrow

Lois West

Hugh Gladwin, Major Professor

Date of Defense: April 17, 2003

The thesis of Cecilia Nana Derby is approved.

Dean Arthur W. Herriott College of Arts and Sciences

Dean Douglas Wartzok University Graduate School

Florida International University, 2003 
(C) Copyright 2003 by Cecilia Nana Derby

All rights reserved. 


\section{DEDICATION}

I dedicate this thesis to all exploited Ghanaian maidservants - they have been my inspiration. 


\section{ACKNOWLEDGMENTS}

Writing a thesis on 'A Conceptual Framework for Understanding Child Slavery' using existing literature and research has been a challenge. The challenge was one I could meet with the great assistance, guidance and support of my professors, family and friends. I owe this work to them all. I am greatly indebted to Dr. Hugh Gladwin, who is the chairperson of my committee. I will always be indebted to you, Dr. Gladwin, for the role you played in my enrollment at this university. I also acknowledge my gratitude to Drs Betty Hearn Morrow, Barry Levine and Lois West. Apart from helping with the supervision of this thesis, these professors have always shown great interest in and support for my academic and professional development as a Sociologist. Additionally, I am grateful to my older brother, Dr. Frank Wallace Derby, for his role in my education. He has always been available as a role model and advisor. Similarly, I say a big thank you to Drs Julia A., Barbara Walker and Christina Gladwin for your support and encouragement. My heartfelt appreciation also goes to Frank Mends, April Dawkins, Jonathan Bulley, Julius Obasohan, Dr. Charles Nunoo, Garth Crosby, Michelle Lamarre, Cristina Finlay and Arelis Lopez. To my mother and the entire family, I say thanks for always being a great pillar to lean on. 
ABSTRACT OF THE THESIS

\section{A CONCEPTUAL FRAMEWORK FOR UNDERSTANDING}

CONTEMPORARY CHILD SLAVERY

by

Cecilia Nana Derby

Florida International University, 2003

Miami, Florida

Professor Hugh Gladwin, Major Professor

This thesis developed a conceptual framework aimed at enhancing our understanding of contemporary child slavery. A new variety of slavery exists today, the result of forms of forced servitude that existed alongside slavery many centuries ago. This is tantamount to slavery. There is, however, a critical lack of awareness about important aspects of the reality of this new child slavery. The framework and definitions of slavery in usage today, though interesting and sufficient to cover historical situations, are unable to adequately describe the conditions of the child slavery. Using existing literature and research, this thesis conceptualized children's labor in a manner that allows a clearer perception of the exploitation of their labor within and beyond the household. Explanatory factors such as culture, the age of victims, the number of hours worked and the ability or not of the victim to volunteer or withdraw their participation in the specific activities were employed to determine if particular situations should be considered as child slavery, repressive child labor or merely as child work. Important distinctions were made between the use of children's mental and physical energy in defined activities. 
I. Introduction ................................................ 1

Child Labor versus Child Slavery: Clarifying the Continuum.......... 1

Conflicting Usage of Concepts ............................ 2

Duality in meaning of the Concepts of 'Child Work' .......... 2

Differences in Economic Development and Socio-

Cultural Values ............................................ 3

Euphemistic Use of the Expression "Child Labor"

to Represent Child Slavery................................. 5

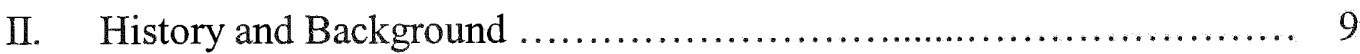

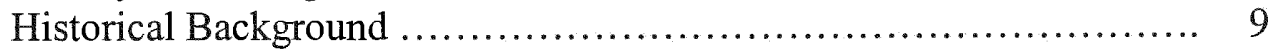

Forms of Permanent Forced Servitude..................... 10

Modern Slavery ................................... 10

Modern Serfdom ................................... 10

Forms of Temporary Servitude ........................... 11

Debt Bondage .................................... 11

Indentured Servitude ............................. 12

Evolution of Contemporary Slavery ............................. 12

The Distinction between Contemporary and Traditional Slavery ........ 16

III. The Definition of Slavery and A Review of Literature ................ 19

Patterson's Definition with its Emphasis on

Natal Alienation .................................................... 19

The 1926 Slavery Convention ................................... 21

More Recent Definitions ........................................ 22

Causes of Contemporary Slavery ............................... 24

Chapter Summary and Conclusion ................................... 26

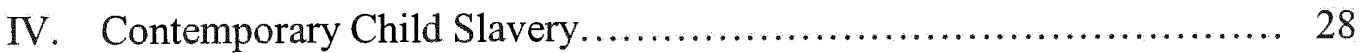

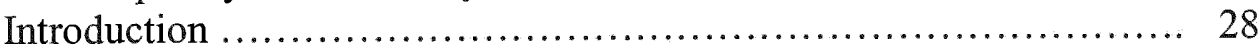

Sources of Information ......................................... 28

The New Forms of Slavery ........................................................... $\quad 30$

Cultural Forms of Contemporary Slavery ......................... 31

The Trokosi System of West Africa ........................ 31

The Slavery of the New Labor Relations ................................. 34

Sources of Recruitment ................................ 34

Types of Slavery of the New Labor Relations .............. 38

a. Domestic slavery ............................. 38

b. Contemporary Slavery in Agriculture,

Industry and Other Occupations ................ 44 
c. Prostitution ..................................... 47

Chapter Summary and Conclusion ....................... 49

V. Summary and Conclusions ................................... 50

Limitations of the Thesis ................................ 54

Recommendations ...................................... 54

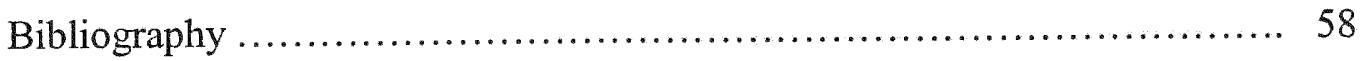

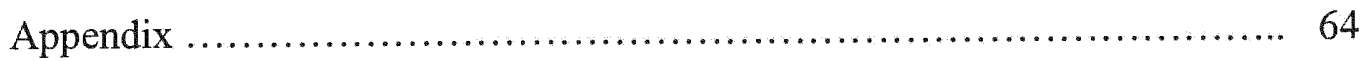




\section{Chapter One}

\section{INTRODUCTION}

Child slavery lives with us today. It is different from other types of slavery in ways to be described in this thesis. The differences present obstacles to understanding the extent and causes of child slavery today. This problem arises because the framework and definitions of slavery currently used in sociology and anthropology, though interesting and sufficient to cover older (historical) situations, are unable to describe adequately the contemporary conditions of child slavery. The deficiency in definition, in particular, makes it difficult to discuss child slavery in any meaningful way. It also makes it difficult to coordinate the practical work being done to combat child slavery. This thesis develops an original framework that aims to enhance our understanding of contemporary child slavery. It draws a careful and necessary distinction between definitions of child labor and child slavery. Specific instances of slavery and child slavery in contemporary societies will also be described.

\section{Child Labor versus Child Slavery: Clarifying the Continuum}

Here the distinction between child labor and child slavery is introduced. This distinction has been necessitated by a general lack of clarity in the conceptualization of child labor exploitation. The lack of clarity is a result of four factors outlined in the following sub-sections. After discussing these factors, a preliminary distinction will be made between child labor and child slavery. This will be followed with a historical overview of slavery in chapter two. In chapter three, existing definitions of slavery will be analyzed while chapter four uses case studies of child labor to determine if 
contemporary slavery exists. Chapter five provides a summary and conclusion of the thesis, reinforces the main ideas drawn from the analyses, discusses the generalizability and limitations of the findings, and recommends a remedial strategy that takes note of the important distinction in definition that policy makers and others involved in eradicating slavery of all kinds need to make.

\section{Conflicting Usage of Concepts}

The first source of misunderstanding involves the synonymous use of the terms 'child labor', 'child labor exploitation', 'child abuse' and 'child slavery'. One could substitute child abuse (or child labor abuse) with child exploitation (child labor exploitation). To exploit, according to the Webster's New World College Dictionary ( $4^{\text {th }}$ Edition) is "to make unethical use of for one's own advantage or profit; specifically without giving a just return." In the same dictionary, the second meaning of 'abuse' means (a) "to hurt by treating badly; mistreat (b) to inflict physical, sexual, or psychological harm upon" (ibid). Given these meanings, it is logical that the concepts of 'child labor exploitation' and 'child labor abuse' are used correspondently. Exploited children might work long hours, are probably denied the chance to participate in formal education and might never be remunerated for the services provided. Nevertheless, child slavery cannot be used interchangeably with the concepts of child abuse and child labor exploitation. Slavery goes beyond mere labor exploitation

\section{Duality in Meaning of the Concept of 'Child Work'}

The second source of confusion stems from the dual nature of children's work. Children's work may be negative or positive. However, the use of the concept of 'child 
labor' implies unacceptable use of children's energies as explained above. This constitutes the negative component of child work. It refers to the exploitation of children's labor, some forms of which could constitute slavery. When positive, children's work is considered functional to their socialization and to their families. In the Handbook for Parliamentarians No. 3: Eliminating the Worst Forms of Child Labor (ILO's Practical Guide to Convention 182), the International Labor Organization (ILO) and Inter-Parliamentary Union (2002), describe children's work as positive if it contributes to the welfare of their families, provides "them with skills, attitudes and experiences..." and help "...them to be useful and productive members of society during adulthood" (International Labor Organization and Inter-Parliamentary Union, 2002: 15). Through children's work, societies instill in their young work expectations and conformity to the general social order. The children are provided with skills, which in turn enable them to contribute to their families' incomes.

UNICEF's Convention on the Rights of the Child (CRC) notes that children are not the properties of their parents or families. Their basic rights to participate in formal education, have an uninterrupted childhood and access to good food, health and shelter must not be traded for a job to help the family. If children work in order to support their families while their own rights are violated, it is exploitation and thus negative.

\section{Differences in Economic Development and Socio-Cultural Values}

The deficiency in infrastructure and educational facilities that characterize many a Third World country coupled with the sort of socialization that children may experience in these countries can impact the meanings of child labor exploitation, and for that matter, 
child slavery. Poverty often requires parents to allow their children to work. As discussed above, this can be necessary to the family's survival and so cannot be readily defined as exploitative.

In addition, in some cultures, children's engagement in certain economic activities is considered a part of their socialization and rites of passage. Such rites vary among different cultures. The common ones are naming ceremonies and puberty rites. As regards puberty rites, van Gennep (1960) distinguishes between social rites and physical rites. Whereas physical rites consist of physiological differentiation that occurs in boys and girls as they reach puberty, the social rites include special ceremonies and socialization performances that are geared towards the initiation and integration of the subjects into the socio-economic communities of the wider society (van Gennep, 1960). Social rites extend over a long period, depending on the intended occupation of the child. At the end of the period, it is expected that the child, who should be closer to becoming a young adult, must have learnt a trade already. Among the Elema of the Papuan Gulf, for instance, the initiation processes begin when the boy is five years old, and at the completion, he should have become a warrior who is ready to marry (ibid.). It is against this background that in the International Year of the Child (1979), the Anti-Slavery Society provided the following definition of child labor exploitation to the United Nations:

...the employment of children in conditions which, taken together and viewed in the context of the social and economic background of the region, are likely to be harmful to their mental, physical or moral and eventually to the development of their potential (Sawyer, 1988: 13). 


\section{Euphemistic Use of the Expression "Child Labor" to Represent Child Slavery}

The fourth reason for confusion in the conceptualization of children's labor exploitation has to do with the question of whether child slavery actually exists. It is consistent for 'child slavery' to be considered a component of 'child labor exploitation'. However, there is a great dissimilarity between 'child slavery' and 'child labor'. In their general use of the concept of 'child labor' to represent children's labor exploitation and slavery, the United Nations (UN) and its subsidiaries including the ILO have almost failed to highlight any distinction between child slavery and child labor. In fact some of what the ILO defines as child labor is virtual slavery.

Child slavery, the worst and most deplorable form of labor exploitation and abuses that minors may be subjected to, is often treated as a subset of the worst forms of child labor exploitation. Slavery is usually identified by the processes through which it arises. In the 2000-2001 progress report on ILO's International Program on the Elimination of Child Labor (IPEC), the authors describe their subjects as children who are mostly victims of the "worst forms of child labor, which include slavery, bonded labor, drug trafficking, commercial sexual exploitation, domestic labor, armed conflict and all other physically and morally hazardous types of work" (ILO, 2002a: 9). While none of these conditions qualifies as old slavery because the victims cannot be claimed as the legal possessions of their perpetrators, this particular report and others imply that these conditions are the bases of contemporary slavery. However, in these reports there is no clear distinction between labor exploitation and slavery.

From the above, two questions are asked: What are the defining characteristics of child slavery? And under what circumstances would we consider child labor exploitation 
to be merely repressive and thus non-slave-like? The characteristics of slavery include the loss of free will, the subjection of the victims to control through violent threats and long hours of work without commensurate remuneration if paid at all (Bales, 2000, 1999). Rationally, when children's labor is exploited without the loss of free will and control through long hours of work and violent threats, the victims could only be said to have suffered repressive labor exploitation. The worst scenario is for them to be underpaid. Sawyer (1988) has cautioned against the possibility of categorizing low paid workers as slaves. In his opinion, low paid workers are not slaves because they may never be content with their incomes and complaints about their wages could be recurrent. Nevertheless, when underage children are bonded and bullied to work, at times in hazardous occupations, while being put through physical and verbal abuses, they cannot be categorized as merely exploited wage laborers, but slaves. Convention on the Rights of the Child (CRC) defines children as all persons who are less than 18 years of age. The minimum working age is however set at 15. Exploitation of children's labor is not considered slavery in this thesis unless in addition to being exploited as above, the victim suffer the loss of free will, is subjected to long hours of work and coercion through violent threats. Additionally, children below the minimum working ages are considered immature and not knowledgeable enough to give consent to their employment. Their particular working conditions are thus considered slavery.

Given these observations, this thesis defines child slavery as "the coercive engagement of children's labor under conditions that conflict with the victim's cultural practices, compel them to work long hours without proportionate remunerations, deprive them of their rights to formal education and their free will to volunteer participation in 
the said occupation." Although these slaves are not considered the exclusive owners of their 'employers', their labor belongs to the employers. 


\section{Chapter Two}

\section{HISTORY AND BACKGROUND}

The introduction above presented some of the definitional problems in conceptualizing child slavery. Before continuing the work of seeing whether child slavery exists today, it is necessary to consider slavery from a historical perspective. Once the current existence of slavery has been established, the thesis returns to the question of child slavery.

\section{Historical Background}

Two forms of forced servitude have existed in societies. They are permanent and temporary forms of forced servitude. Permanent forms of servitude included slavery and serfdom. Debt bondage and indentured servitude constituted a major part of temporary forms of servitude. For moral reasons, forms of permanent servitude have been outlawed from many societies. Legislature banning the permanent forms did not cover the temporary forced servitude. Thus although there have been several attempts in recent times to eliminate them, they have already evolved into slavery. This historical overview of slavery is outlined in the next section and followed by a discussion of the evolution of contemporary slavery. The following subsections discuss these forms of servitude.

\section{Forms of Permanent Forced Servitude}

Modern slavery. The forms of permanent forced servitude were made up of slavery and serfdom. Slavery, "the status or condition of a person over whom any or all of the powers attaching to the rights of ownership are exercised" (The 1926 Slavery 
Convention) came to be known as the modern slavery in order to distinguish it from similar kinds of exploitation that existed before the $13^{\text {th }}$ century. Slavery is said to have emerged in $6800 \mathrm{BC}$ when the onset of private ownership and improvements in technology led to warfare and the capturing of enemies who were forced to work (Bales, 2000 ) on private properties. The captives' lives were spared in exchange for the services to be provided on their captors' properties (Meltzer, 1980; Archer, 1988). In fact the word 'slave' has its roots in the Latin word servus, which means "a person whose life has been spared (servatus) by the captor" (Archer, 1988: 267). In earlier nomad or hunter gatherer societies, captives were killed because there was no economic need for them (Meltzer, 1980). There was also not enough food to feed them (Meltzer, 1980). When slavery is used in this thesis without clarification, it refers to modern slavery. Slavery in this context is synonymous to the old, chattel or traditional slavery because they carry the same meaning.

Modern serfdom. Serfdom is the other source of permanent servitude. Like modern slavery, the concept of 'modern' was used to qualify serfdom in order to distinguish it from those existing before the $13^{\text {th }}$ century. The 1956 Supplementary to the Slavery Convention of 1926 defines serfdom as

the tenure of land whereby the tenant is by law, custom or agreement bound to live and labour on land belonging to another person and render some determinate services to such other person, whether for reward or not, and is not free to change his status"

Serfdom existed in medieval western and eastern European peasant societies (Bush, 2000). The tenants were the serfs or vassals who were considered under the law, by customs or through agreement as properties of the lords. The lords are the landowners. 
The serfs were attached to the lords' estates or the lord's person and were disposable through sales, either separately or together with the estates (Bush, 2000). Although there is no exact equivalence of serfdom in contemporary slavery, the provision of brothels and massage parlors for victims to work and receive just a percentage of the proceeds of their labor, usually characterized with violent threats, is similar to the relationship that existed between the serfs and their lords. Like the lands that were accessible to the serfs, these brothels represent a resource to the victims although their particular experiences are more dehumanizing and coercive.

\section{Forms of Temporary Forced Servitude}

Debt bondage. This resulted from financial obligations that were due to the supposed masters or the beneficiaries of the services. In the 1956 Supplementary to the 1926 Slavery Convention, debt bondage is defined as

"the status or condition arising from a pledge by a debtor of his personal services or those of a third person under his control as a security for a debt, where the value reasonably assessed of those services rendered is not applied towards the liquidation of the debt or the length and nature of those services are not respectively limited and defined."

The servants were required to provide free services to their debtors. Kevin Bales (2000) identifies two types of debt bondage. In the first, the slaves' labor and their lives are used as collateral for the acquisition of the loans and are thus obligated to provide free labor to repay the loans and their interests, while in the second, the victims become bonded slaves when they violate the loan agreements (Bales, 2000; 1999). A third category of servitude stemming from loans is the debt slavery, which is more permanent than debt bondage. 
The difference between debt bondage and the debt slavery is that under the latter, the repayment of the loans did not guarantee one's freedom.

Indentured servitude. Like debt bondage or debt slavery, indentured servitude resulted from financial obligations. Debtors, according to Bush, traveled long distances to work on plantations, and their employment was based on indenture contracts. The indenture is a contract that bound men and women for three to five years of service in a distant land (Bush, 2000). There were two phases of indentured servitude (Bush, 2000). The first existed in the period between the $17^{\text {th }}$ and $18^{\text {th }}$ centuries, while the second stretched from the $19^{\text {th }}$ through early $20^{\text {th }}$ Centuries. The indentured servant would remain the property of the person who paid the travel expenses until they were sold to a master. This master will either exploit them till the expiration of the indenture, or sell them (Bush, 2000). Merchants privately organized the first phase of indentured servitude, while governments conducted the second (Bush 2000).

\section{The Evolution of Contemporary Slavery}

Contemporary slavery exists today because slavery has never been eliminated from societies. In addition to the causes that will be outlined in the next chapter, the length of time that took some countries to abolish the old forms of slavery, coupled with the continued existence of the phenomenon in countries such as Mauritania, provided and continue to provide the sources of reference to the perpetrators of contemporary slavery. Debt bondage and indentured servitude were not considered as dehumanizing as slavery and serfdom, and thus were neglected in the attempts to eliminate slavery and serfdom from societies. Laws were established to eliminate the old slavery and serfdom, while 
others were, as already mentioned, geared towards an enhancement of the use of temporary servitude. With the elimination of modern slavery and serfdom from many societies, indentured servitude and debt bondage became prominent sources of labor supply for agricultural plantations in the Third World (Bush, 2000). Over time, these forms of temporary servitude assumed attributes that are similar to slavery. This calls into question the efficacy of the many conventions that have been adopted to eliminate slavery from contemporary societies.

While the laws established to maintain the free supply of labor no longer exist, the nature and form of contemporary slavery indicate that the absence of these laws did not eliminate forced servitude from societies. Among such laws was a 1780 Pennsylvanian law that required that slave children remained bonded until the age of 28 (Bush, 2000). There was also a British statue of 1833 , which required that all former slaves served their ex-masters for an additional six years (Bush, 2000). These and other such laws allowed the old forms of servitude to linger. When the former slaves were eventually set freethat is when they were not bound by any law whatsoever to provide free services to any categories of people - vacuums were created on plantation and in households. As is the case with almost all social phenomena, new structures or positions that would fill these vacuums evolved.

The first major source of free labor immediately following the abolition and outlawing of slavery was the exploitation of the then colonized populations. To facilitate the eradication of this kind of labor exploitation and to prevent it and other such forms of exploitation from degenerating into slavery, the League of Nations in 1926 approved the first Slavery Convention (ILO, 2001a). Among others, this convention prohibited all 
aspects of slave trade, and the acts of capturing, acquiring or disposal of persons with the intent of reducing them to slavery (ibid.). For the same purpose of ensuring that forced labor did not develop into slavery, the ILO's Convention 26, the Forced Labor Convention, also came into force in 1930. In 1949, the Convention for the Suppression of the Traffic in Persons and Exploitation of the Prostitution of Others was adopted. This prohibited the procurement, enticement or leading of another person for prostitution, even when there was consent.

None of these conventions were able to help circumvent the continued existence of the new slavery. Apart from the fact that they did not directly address strategies to eliminate slavery from societies, they had been instituted too late. Forms of temporary forced servitude had already assumed slavery characteristics. In 1918, the British Governor to Hong Kong is purported to have stated that the largest number of households that could afford it were using girls as domestic slaves (Bales, 2000). Girls were being sold into slavery. It was estimated in 1952 that 40,000 Japanese were sold into prostitution in brothels. The brothel owners paid between US $\$ 25$ and US $\$ 100$ per child (ibid.).

Events of the 1940s and 50s also intensified the development of temporary forced servitude (ILO, 2001a). Some former colonies had already gained political independence. Struggles had also begun for other countries to gain their independence too. Outside the colonies also, labor exploitation was rife because of the impact of the Second World War on labor. People were working under deplorable conditions. It was anticipated that there was going to be an increase in illegal exploitation and trafficking of women and children and the trafficking of same for exploitation under slavery conditions. 
Given this background, the 1956 Supplementary Convention to the 1926 Slave

Convention was considered necessary for the prevention of slavery's reestablishment.

This convention prohibited debt bondage, serfdom and

[a ]ny institution or practice whereby a child or young person under the age of 18 years, is delivered by either or both of his natural parents or by his guardian to another person, whether for reward or not, with a view to the exploitation of the child or young person or of his labour.

As will be shown in chapter four, this Convention and more recent others have all failed to protect children and other vulnerable members of our communities from labor exploitation, and from slavery. More and more children continue to be kidnapped, trafficked and forced into sexual or domestic slavery. It is estimated that over 400 million children work today (Cox, 1999). An estimated 250 million of these child workers are exploited. It is further estimated that $41 \%$, i.e. about 80 million of all African children aged between 5 and 14 years are victims of child labor exploitation (African Business, 1998; Innocenti Research Center, 2002). It is envisaged that by 2015, this estimate will increase to 100 million given the present state of socio-economic conditions of African countries (ibid.). Out of an estimated 220 million children aged between 5 and 14 in India, over 100 million are expected to be out of school (Mishra, 2000). They provide a ready source of free labor for exploitation (ibid) in industry, agriculture, within the household and for sexual slavery. Hundreds of these are contemporary slaves. 


\section{The Distinction between Contemporary and \\ Traditional Forms of Slavery}

In chapter one, this thesis examined how contemporary slavery evolved out of existing forms of forced servitude that were earlier neglected in efforts to eliminate slavery from societies. Forms of temporary forced servitude are thus seen as a link between the old slavery and the new. In the following paragraphs, a distinction is made between contemporary (new) slavery and the traditional. The differences so observed are outlined in an attempt to illustrate further, the reality of the new slavery.

The first factor that distinguishes the new slavery from the old is the nature of ownership. Traditional slave owners had legal evidence supporting their ownership (Bales, 1999, 2000, Palmie, 1995). Contemporary slaves are not legally owned this way. They are therefore disposable (Bales, 1999, 2000). Originally, the only legal way to dispose of slaves was to sell or transfer ownership, which will be backed by legal documents. Contemporary slaves, on the other hand, is exploited and then gotten rid of when they cannot generate any incomes to their exploiters. In India, for instance, creditors usually ask for replacement when bonded children become indisposed and less able to work long hours (Mishra, 2000). Additionally, contemporary slaveholders are not obliged to maintain their victims. Unlike the old system, a majority of the contemporary slaves either live independent of their 'masters'. When the victims live in premises provided by the perpetrators, they fulfill significant parts of their incomes towards their maintenance. Trafficked women may never be able to accomplish their dreams of improving their own lives and those of their dependants because they are forced to lose large sums of their incomes as living expenses (France, 2000). 
Another factor distinguishing the two types of slavery is their relative worth. Old slaves were very expensive. The slave of the $19^{\text {th }}$ century cost between US50, 000 and US100, 000 per person in today's currency (Bales, 1999, 2000), while the contemporary slave may be obtained even for free. Among other factors, the new slaves emerged because of population explosions that were concentrated in the rural regions of less developed countries (ibid.). Since they are in excess supply, they are more profitable than the old. If a bonded slave could work in a bead or glass-making factory for the rest of her or his life in order to settle only $\$ 30.00$ (Bales, 2000), then indisputably slaveholders make huge profits off their victims.

The last distinction between contemporary slavery and the traditional is the role that race and ethnicity played in the enslavement of some people (Bales, 2000, 1999). In the past, it was the norm for slaves to be obtained from 'outside' groups, which were racially or ethnically defined. Apart from the few instances of traditional slavery in places like Mauritania, economic vulnerability is the single most important factor leading to the enslavement of others in societies.

The new forms of slavery have been analyzed in terms of various theoretical frameworks. The new economics theory of migration identifies the family or household as an important player in the decision for the victim to migrate. It suggests that migration decisions are made within larger social units of interrelated persons such as the family or households, rather than in isolation by the individual actor. In this way, the family will successfully maximize expected income while minimizing risks to income (Stark 1991; Taylor 1994). The sale and trafficking of young and vulnerable children around the world for labor and sexual exploitation, or their migration from rural to urban regions 
(US State Department, 2001) is usually contracted through parents or relatives (UNICEF, 1999. Children enter the labor force through family channels so that the 'employers' adopt a pseudo-parental role, which serves to obscure the extent of exploitation being meted out to them (Verlet, 2000).

Some sociologists and anthropologists question the sincerity of efforts of governments and international non-governmental organizations to combat labor exploitation. The structures that have been established to ward off slavery in contemporary societies, according to some world systems theorists, are but a reproduction of those historical structures and processes that enhanced slavery in previous historical systems (Grosfoguel and Cervantes-Rodriguez, 2002). Theoretical debates of the core-periphery relationships assert that the Third World has been plunged into poverty because of the disadvantaged positions that they occupy within the world system. With absolute poverty heightened in these economies, women and children have become increasingly vulnerable and their positions have been exploited by crime syndicates and traffickers (Bales, 2000, 1999).

World systems theorists identify different historical structures each of which is characterized with economic relationships that although unique to the specific historical stage, are more or less universal. Factors that ensure change in these systems are also responsible for the historical changes in slave relationships. They indicate that for as long as the world systems continue to be reproduced, slavery will remain a part of societies. Nevertheless, the conditions and relationships defining slavery in any specific epoch will change according to the system, as well as the size of the respective societies. Using Polanyi's theory of reciprocity and modes of integration, they argue that small kin 
based societies, for instance, integrate their members through reciprocal exchanges that depended on culturally defined rights and obligations (Chase-Dunn and Hall, 1997). In large and hierarchically complex societies, however, redistributive forms of exchange executed by a formal authority replace those reciprocal exchanges existent in small societies. Following this, slavery in small kin based societies are limited by their reciprocal relationships, while in the contemporary capitalist world system, slave relationships are expected to be based on the commodification of slave statuses. 


\section{THE DEFINITION OF SLAVERY AND A REVIEW OF EXISTING LITERATURE}

Chapter one drew a distinction between child labor and child slavery. The preceding chapter shows that forms of slavery persist in modern times. In this chapter, the thesis continues to analyze the incidence of contemporary slavery by discussing some selected definitions of slavery in general. The chapter concludes with a review of the literature on the causes of slavery in general, and the contemporary type in particular.

Patterson's Definition with its Emphasis on Natal Alienation

Orlando Patterson (1982) defines slavery as "the permanent, violent domination of natally alienated and generally dishonored persons" (pp. 13). As an unfree person who was legally and permanently ostracized from the many social structures and institutions that made up their societies, the slave was without a doubt, a dishonored person. But this permanency constitutes a major flaw in Patterson's definition, with regard to contemporary slavery (although it does apply to many earlier forms of slavery). The relationship between the new slave and their owners is the least permanent. Their statuses are outlawed in all societies and so they cannot be permanent properties of their owners. It is their labor that is of significance to the contemporary slave-owner (Bales, 2000, 1999).

Another fault in Patterson's definition is the inherent assumption that all slaves are natally alienated. Natal alienation used to be a major feature of the old, traditional slavery. Some people were born into slavery. They were natally alienated because even 
before birth, the traditional slave was legally denied kinship ties and identities that are true for free men and women. Unless freed, a person born a slave would remain so until death. His children who were also slaves and thus did not have any rights, belonged to the master. These children were brought up with the master's family and began to work as soon as possible. The situation for contemporary slaves is different. While it is unquestionable that some new slaves may never be able to communicate or see their families again, this is not a regular feature of the new slavery. Given the fact that the contemporary slave owner is only interested in the slave's labor and his enthusiasm for spending as little money as is possible on that labor, the new slaves may never be alienated from their families. In fact there are some contemporary slaves, like the bonded slaves in India who live with their families and commute to work everyday.

The non-existence of natal alienation notwithstanding, both traditional and the contemporary forms of slavery are characterized with some sort of alienation. From Kopytoff's (1986) point of view, this takes place through processes that enable exploiters to snatch their victims from their families and original identities while introducing them to new ones. In his article Cultural Biographies of Things: Commoditization as Process, Kopytoff calls for an understanding of the cultural processes or "culturally informed economic biographies" through which individuals lose their original identities to assume new social statuses such as slaves. Commoditization involves the dehumanization of the victims through their capture, sale or resale (Kopytoff, 1986). He suggests that when individuals become dehumanized, their original identities such as those internalized while living with their parents and close relations, are lost. They become replaced with new identities through rehumanization. For the contemporary child slave, rehumanization 
would involve the internalization of roles associated with their underdog slave statuses. The point of removal from their original households, dehumanization and rehumanization make up the different phases of their culturally informed biographies. These biographies tend to be spatially (or culturally) and temporally situated. As Davis (1984) points out, the type of slavery and the conditions under which the victims live and work are functions of culture.

\section{The 1926 Slavery Convention}

Slavery, whether old or new, entails relationships that are characterized with some claim to ownership. It is either the absolute ownership of the victims as properties as it is the case with the old or chattel slaves, or the ownership of their labor as is characteristic of the new slaves. None could be inferred from Patterson's definition. The 1926 Slavery Convention defines slavery as "the status or condition of a person over whom any or all of the powers attaching to the rights of ownership are exercised". This goes beyond the fact of ownership to cover all the losses that the slave encounters for not owning their lives. Slavery is defined in this Convention in terms of exploitation and alienation, rather than natal alienation as Patterson postulated. The primary goal for possessing slaves is huge economic gains, hence the deprivation of the slaves from enjoying certain facilities. When subjected to the rights of ownership as used to be the case with the old slavery, the victims were treated as properties and thus could not enjoy the benefits of possessing any significant properties themselves. 


\section{More Recent Definitions}

Not all attempts to define contemporary slavery are successful. The most confusing of all the definitions is that stated in UNHCR's Fact Sheet \# 14. In this document, the new slavery is defined to include traditional slavery and

the sale of children, child prostitution, child pornography, the exploitation of child labour, the sexual mutilation of female children, the use of children in armed conflicts, debt bondage, the traffic in persons and in the sale of human organs, the exploitation of prostitution, and certain practices under apartheid and colonial régimes (UNHCR, undated).

A lot has been said about children's labor exploitation, traffic in persons, prostitution and debt bondage. Barry (1984) has argued that child pornography is forced and thus slavery. In her opinion, to engage in pornography requires consent. But consent in turn demands knowledge, in this case sexual knowledge, and maturity. She argues, "[i]f knowledge is a requirement for consent and maturity is necessary for sexual knowledge, then the use of children in pornography is by definition forced, and therefore a form of sexual slavery" (Barry, 1984: 99). Children are immature and lack sexual knowledge. Therefore, their participation in child pornography is not based on consent, hence forced and thus slavery. This explanation shows why pornography is slavery. Categorizing the sale of human organs and female genital mutilation is as slavery is, however, overstretching the debate. Indisputably, babies and young children who undergo female genital mutilation may not be mature enough to be knowledgeable about the practice and thus cannot give adequate consent. Nevertheless, it is more appropriate to perceive this as a repressive cultural practice rather than slavery. It is not slavery because there is no labor exploitation involved. In the same manner, the sale of human organs could not be conceptualized as slavery. 
Two definitions that highlight the situation of the contemporary slavery are those by Kevin Bales (2000) and Kathleen Barry (1984). Barry's definition focused exclusively on sexual slavery, while Bales' was more general. Bales (2000) defines slavery as "a social and economic relationship in which a person is controlled through violence or its threat, paid nothing, and economically exploited (Bales, 2000:3). Barry, on her part, sees sexual slavery as existing in "ALL situations where women or girls cannot change the immediate conditions of their existence; where regardless of how they got into those conditions they cannot get out; and where they are subject to sexual violence and exploitation" (Barry, 1984: 39-40). These two definitions highlight the contemporary slaver's sole interest in the victim's labor while illustrating the means through which the victim loses free will and control.

Whether exploited in the manufacturing sector or within the households as domestic servants or on farm plantations, the contemporary slave usually finds it difficult to get out. In the case of sexual slaves, they are often threatened with death if they ever venture to escape. As regards domestic servants, there have been newspaper reports in which children who were able to escape could not locate their families because they were snatched away at very tender ages (Accra Mail, 2001). The inability to locate one's family or homes exists also with children who were kidnapped and forced into prostitution. In the documentary The Day My God Died, some children were rescued through the joint efforts of the Maiti Nepal Transit Home (a transit center for rescued sex slaves) and the International Justice Mission (IJM). However, some of them could no longer trace their families. 


\section{Causes of Contemporary Slavery}

Factors or "entities that work in some specified ways" (Chase-Dunn and Hall, 1997: 20) in the system logic of the current world system also cause changes in social phenomena such as slavery. These factors include population explosions, economic policies, culture, and the associated social and technological changes. Immediately after World War II, there were population explosions the largest of which occurred in the Third World (Bales 2000, 1999). This worsened the incidence of poverty in those regions, particularly rural poverty, and intensified economic vulnerability in the affected areas. There were dramatic increases in potential labor supply, causing wages to plummet tremendously. Many people have had to offer their services under slavery conditions (ibid.).

There was also rapid socioeconomic change around the same time (Bales 2000, 1999). Many countries became politically independent in Africa and Asia. Many of these countries were dominated by dictatorial governments, while others suffered civil wars. With the support of core countries, their political leaders managed to siphon resources out of their respective countries to build armies and personal fortunes. They run their countries into huge foreign debts, as a result. This further impoverished the already suffering masses in these countries (Bales, 2000, 1999). Unfortunately, the few business elites in these countries also exploited the situation to their own advantage, contributing also to widespread impoverishment.

The poor conditions worsened when the International Monetary Fund (IMF) and the World Bank initiated development programs that failed to stimulate growth and stability in participating poor countries (Donkor, 1997; Gladwin 1991). Families and 
other kin groups were displaced from their lands, small scale farming that supported rural households was replaced with cash crop agriculture, and proceeds from farming diminished because of the government's goal to provide cheap food to the urban community. This, coupled with the existing cheap labor, compounded the situation of the poor because they were driven further to offer their services at ever cheaper rates (Bales, 2000).

Another factor that has influenced the surge in child labor exploitation and slavery is culture (Burra, 1995; Tucker, 1997, Seabrook, 2000). Girls are more likely to end up in slavery or domestic servitude because of the traditional notion in some societies that their place is in the kitchen. Even though countries appreciate the need to educate their young, much significance tends to be placed on cultural values rather than child educational development. Mishra (2000) points out that compulsory education is not implemented in India because the consideration of the cost of education "supervened over the desirability of the objective" (pp. 40). Indians also have the traditional notion that if all children were enrolled in school, there would be increased unemployment (ibid.). Indians believe that some people "are ordained to work with their minds and to rule and others to work with their hands and be ruled, and that education should reinforce rather than seek to break down this division" (Mishra, 2000: 60). This notion justifies the deprivation of education to people from certain backgrounds in India. Slave children's educational background therefore tends to reflect their parents'.

Advanced technology and information systems are also factors responsible for contemporary slavery. Part of the contemporary world system is the global media through which information, news and cultural patterns are easily disseminated across 
borders and within a short period. The content of the information so transmitted goes a long way to perpetuate slavery in societies. According to Grosfoguel and CervantesRodriguez (2002), the global media is responsible for the positive projection of core cultures with respect to race, gender and heterosexuality. The 'advanceness' of the core economies are projected in these media propaganda, thus creating a desire among the people in the periphery to migrate to the core. With negative propaganda made about the periphery, dangerous tourists and traffickers are provided information about the vulnerable in contemporary societies as well as the sources of potential slaves. As would be discussed in chapter four, many women and children end up in prostitution, domestic servitude or work on farms under slavery conditions because of their failed attempts to migrate to advanced industrialized countries to seek greener pastures.

\section{Chapter Summary and Conclusion}

This chapter focused on three main issues. These are existing definitions of slavery in general, causes of slavery and the distinction between contemporary and traditional slavery. As is to be expected, earlier definitions of slavery were based on concepts that are not applicable to the contemporary situation. Among these concepts are permanency and natal alienation. It was emphasized that contemporary slaves cannot be categorized as permanent because they are not owned. Moreover, contemporary slaveowners are particularly interested in the economic worth of their victims, and so are prepared to use them for as long as such exploitation would not cost them much, if any at all. In fact this lack of permanency in contemporary slavery is a major part of the distinctions that are drawn here between contemporary and traditional slavery. Using 
more current definitions, it is concluded that loss of freewill, working long hours without pay, control through violent threats and the inability of the victim to escape for fear of being murdered or tortured are the major characteristics of slavery. 
Chapter Four

\section{CONTEMPORARY CHILD SLAVERY}

\section{Introduction}

Earlier in chapter one, child slavery was preliminary defined as the coercive engagement of children's labor under conditions that conflict with the victim's cultural practices, compel them to work long hours without proportionate remunerations, and deprive them of their rights to formal education and their free will to volunteer participation in the said occupation. This chapter draws on this definition and the historical and definitional analysis of contemporary slavery to look at current research on child labor to determine if indeed contemporary child slavery is real.

\section{Sources of Information}

This thesis uses existing literature and case studies on child labor and child slavery. The bulk of the case studies are credited to the ILO, the United Nations and their respective subsidiaries and the US State Department. Given the paucity of the literature on child labor exploitation and child slavery, these sources of information have been supplemented with newspaper and other research reports. The issue of child labor exploitation came to light in the 1980s and 1990s. By the end of 1998, the ILO had founded the International Program for the Elimination of Child Labor (IPEC). Subsequent to that, ILO's InFocus Program on child labor: IPEC was created. This made it possible for links between policy development, standard setting and advocacy operational programs intended for the progressive battle against child labor exploitation to be advanced. Among the steps to be taken towards achieving this broad goal is the 
motivation of alliance among governments and agencies, mainstreaming child labor issues while carrying out situational analyses so as to investigate the incidence of child labor in various countries. As a result, many researches have been conducted. Among the countries researched are the Cote d'Ivoire, Tanzania, Nepal, Jamaica and Brazil. These researches focused on child domestic servitude, sexual exploitation and in some cases, the employment of children in the informal sectors. These partially provided the case studies presented in this chapter.

In June 1998, the ILO Declaration on the Fundamental Principles and Rights at Work came into force. Follow up reports on the Declaration advocated research on children's labor. These also served as sources of knowledge about child labor exploitation. Another major source of information was from the Innocenti. Innocenti is a research unit of the United Nations Children Education Fund (UNICEF). Since its inception in 1988, it has provided reliable data on children and their changing needs.

Trafficking is a significant aspect of contemporary child slavery. In order to assess the extent of trafficking and how it impacts contemporary slavery, a report that the US State Department released in June 2001 was used. This report is the outcome of many years of research on trafficking in persons. Data from the report is compiled and presented in Appendix A. The US State Department started monitoring trafficking in today's societies in 1994 when the issue started appearing in its Annual Country Reports on Human Rights Practices. Following this, the Department started monitoring trafficking of women and children for sexual purposes through 186 US consulates and embassies around the world. Its focus was soon broadened to include the trafficking of people of all sexes and their exploitation in agriculture, domestic servitude and 
construction work. In 2000, Congress passed the Victims of Trafficking and Violence

Protection Act which required that the report on trafficking be submitted by June of 2001 . Many countries that were cited in this thesis as origins, destinations or transit centers were confirmed in this report. This report also showed that Third World countries not only serve as source, but also as transit centers, destinations or in some cases, as all of these.

In the analyses of this thesis, findings from these research and newspaper reports were compared in terms of definition of slavery developed by social theorists. Certain attributes are observed to be generally characteristic of slavery. Unless the children are observed to share these attributes, they are not considered to be slaves.

\section{The New Forms of Slavery}

This thesis categorizes contemporary slavery into two. The first is referred to as cultural forms of contemporary slavery. These originate primarily from traditional practices and cultural beliefs. The second is the slavery of the new labor relations. The cultural forms of contemporary slavery are not only repressive, and can deny the victims their rights as human beings, subjecting them to long hours of work without pay, exploitative abuse through violent controls and alienation. The slavery of the new labor relations, so called because of their semblance to the economic relations within the contemporary global economy, is the consequence of the slave-like exploitation of the economically vulnerable in our societies. In some cases, both types of slavery are operative on the same victims. 


\section{Cultural Forms of Cotemporary Slavery}

Conceptualizing cultural forms of contemporary slavery is complicated by the issue of cultural relativism. To argue that certain cultural practices have influenced the enslavement and the slave-like treatment meted out to some members of societies goes against cultural relativism. Being culturally relative means appreciating all cultures as situationally and temporally functional, but the role cultures play become dysfunctional when women and children are committed to slavery through cultural practices. Certain cultural practices place women in more vulnerable positions than men. The implication of this is that slavery of the new labor relations cannot be discretely distinguished from the cultural forms. This thesis defines cultural forms of contemporary slavery to include all forms of slave-like exploitation that stem from the cultural practices of a culturally distinct people.

Using the world systems perspective, this thesis suggests that all things being equal, the cultural forms of contemporary slavery are more likely to exist in pre-capitalist societies because of the role that cultural values play in the continued existence and survival of such cultures. For the most part, cultural forms of contemporary slavery are sustained through patriarchal values such. Below is a case study of a type of cultural slavery that is practiced in some West African cultures.

\section{The Trokosi System of West Africa}

The word trokosi is a derivative of two Ewe words, tro and kosi. Tro means slave, while kosi refers to deity. Hence trokosi literally translates "slaves of the gods" in the Ewe language (Niagia, 2002; Amponsah, 2001). Trokosi is predominantly practiced 
among the Ewe tribes of the Volta Region of southeastern Ghana (Levine, 2003), and to a lesser extent in Togo, Benin and Nigeria (Bales, 2000). This tradition is gender-biased. Innocent female virgins are committed to shrines to pacify the gods of certain specific shrines in those regions for the offences committed by their parents and relations some of whom could be dead. Some of the girls are as young as three. In some cases, the girls are offered to the shrines because their parents or other relations promised to commit them for services that the gods are purported to have rendered them (Niagia, 2002). According to the Director of International Need Ghana, there are over 2000 ritual slaves languishing in some 76 shrines in Ghana alone (Orhin, 2001; Xedia Systems Ltd, 1999). When committed to these shrines, the girls become the properties of the priests who are believed to be the mediators between the people and the deities (Amponsah, 2001). Upon the death of the current priest, the trokosi slave will belong to his successor (Amponsah, 2001). When the girls are ill, the families are obliged to replace her with a healthy virgin (Levine,). At the shrine, the trokosi slave performs domestic chores, works on the priest's farms and provides sexual services to the priests (Amponsah, 2001; Niagia, 2002; Equality Now, 2002; ECM, 2002; Levine, 2003). They are not usually compensated for these services (ibid). Nevertheless, when they work outside the shrine, they are allowed to keep only a small fraction of their proceeds (Levine,).

Although the priests sleep with them, they do not show any affection toward the girls (ECM, 2002). They are frequently raped (Amponsah, 2001). The girls often become pregnant usually at a young age. When that occurs, they are left to cater for themselves and the children on their own. The priests do not regard the trokosi's offspring as their children, but slaves as well. The International Need estimates the 
average number of children per slave girl is four (Accra Mail, 2001). The young mothers and their children eat anything that would help them survive (Levine, 2003). They are not provided any medical services (ibid).

In addition to sexual abuses, trokosi slaves are normally subjected to other forms of physical abuses. They are either beaten or made to kneel down on broken bottles (ECM, 2002). The girls are punished when they refuse to have sex wth the priests, run away to their families, come home late from errands, eat certain produce without permission, and refuse or are unable to run errands (ECM, 2002; Amponsah, 2001).

Situated within a very powerful superstition, families are afraid that any refusal on their parts to send a girl into the shrine would result in untold hardships, tragedies and calamities within the family. The offences that could send an innocent girl into a trokosi shrine ranges between petty thievery through rape and murder. Depending on the severity of the offence, the child is required to serve between 3 and 5 years. However, in order to release them at the end of their terms, the priests usually demand huge prices that include animals, cash and drinks. The families may not be able to afford them. Consequently, the victims would remain slaves for as long as it takes, probably for their entire lives. In other instances, families have refused to redeem their daughters from the shrines because of fear. In 1998, Equality Now showcased Ablah, a 12 year old trokosi who had been committed to a shrine for the circumstances that led to her birth. Her mother became pregnant with her when her (the mother's) uncle raped her (Equality Now, 2002). When a law was passed in June 1998 to abolish trokosi in Ghana, Ablah's aunt refused to redeem her because of the panic that the family could suffer some curses with her return home (ibid). 
The International Need, a Christian non-governmental organization has been involved in activities to free these ritual slaves (Orhin, 2001). The studies of this organization indicate that there are over 30,000 ritual slaves in the aforementioned countries. These exclude those who live in witch homes because their relatives would not accept them back, or because they are afraid to be lynched to death. Together with Ghana's Center for Human Rights and Administrative Justice (CHRAJ), they have freed and rehabilitated 2800 ritual slaves over the last five years. Usually, the freed girls are enrolled in some sort of apprenticeship, particularly, hairdressing and dressmaking.

\section{The Slavery of the New Labor Relations}

Although cultural values are sometimes employed to perpetrate slavery of the new labor relations, the notion that people do not enslave others for the mere sake of being mean, as Bales $(2000,1999)$ suggests, is the main reason for the persistence of the slavery of the new labor relations. People enslave others in order to make economic gains out of them. Even in the case of cultural slavery, the priests exploit the labor of their innocent victims. In the following sections, child slavery in prostitution, domestic servitude and slavery in agriculture and industry are discussed.

\section{Sources of Recruitment of the Contemporary Slave}

A number of factors are identified in the literature as the sources of recruitment of contemporary child slaves. These include parental arrangement, debt bondage, kidnapping, and the incidence of children having had to run away from homes because of abuses. Usually, the type of work that the victim will be engaged in determines the source of recruitment. Domestic workers are observed in the literature to be mostly 
obtained through arrangements with families, acquaintances or intermediary groups. Bonded slaves are usually obtained through family contacts, kidnapping and or trafficking.

Parental role in the recruitment of child slaves. Parental involvement in the recruitment of children for labor exploitation and prostitution ranges from advising their children to accept job offers or promises that would eventually be enslaving. Some families give their children away with the intentions that they may have a better life and probably will be provided formal education (Verlet, 1998; ILO, 2001). But this does not ensure their safety and security. Most families are driven to give their children away in order for the rest of the family to survive (ILO, 2002a). In Egypt where child labor occurs on cotton plantations ( $10 \%$ of which belong to the state), child labor occurs because their parents, ironically, cannot get employment (Mikay, 1997). In an ILO IPEC research conducted in Kathmandu, India, $46 \%$ of their respondents indicated that their relatives were responsible for enrolling them into domestic servitude, $86 \%$ of them showed that their parents advised that they accepted such a job (ILO, 2001b). In some extreme cases, parents have had to sell their children into prostitution (Chidey, 1996).

Intermediary Groups. Intermediary groups specializing in the recruiting and trafficking of children have evolved in recent times. Prior to these intermediary groups, domestic slaves, were most often supplied without cost through acquaintances, friends and relations with contacts in rural communities. Siblings or friends who were already working as domestic slaves also served as a good source (UNICEF, 1999; ILO, 2001). Now, however, more organized intermediary group provides the new domestic slaves. It 
is usual for a number of the victims to sign fake contracts with their recruitors (Bales, 2000, 1999). In Latin America they are known as contratistas. They are labor contractors who make advance payments to their 'victims' and thus subject them to debt bondage and indenture-like contracts that are usually verbal (ILO, 2001). Elsewhere, they are engaged in the kidnapping, trafficking and sale of underage children for sexual slavery. Nigerian intermediaries specializing in the recruitment of prostitutes are known as Mama-Lao (ILO, 2000). Brazilians refer to the intermediaries as empreiteros or gators (ibid).

Trafficking. The 1949 Convention for the Suppression of the Traffic in Persons and Exploitation of the Prostitution of Others perceives trafficking as the procurement, enticement or leading away, for purposes of prostitution, another person, even with the consent of that person. In the contemporary sense, the movement of people from one place to another is identified as 'trafficking' if the migrants are lured to leave their places of origin to be forced to engage in activities that are exploitative and enslaving, and which are usually different from the jobs promised them prior to their journeys. According to the US State Department, an estimated 700,000 women are trafficked yearly in contemporary societies. Generally, victims of forced trafficking originate from developing countries. According to the US State Department (2001) ${ }^{1}$, high-income countries such as the United Kingdom, Canada and France are most likely to serve as transit or destination for trafficking. This report also asserts that at least 700,000 women and children are trafficked across international borders annually, while the US alone receives between 45,000 and 50,000 trafficked victims every year. Some of the victims

\footnotetext{
${ }^{1}$ See appendix A, which is a summary of the report released by the US State Department.
} 
may just be transiting. According to the US State Department (2001) approximately 50,000 women and children are trafficked into the country every year.

Their traffickers use manipulative accounting systems to dupe their victims of huge sums of money. In 2000, some women who were trafficked into the United States agreed to pay between US $\$ 30,000$ and US $\$ 40,000$ to their exploiters (France, 2000). According to International Organization for Migration (2000a), Nigerians who have been trafficked into Italy since 1996 paid between US\$50,000 and US\$70,000.

The International Organization for Migration (IOM) reports the experiences of various trafficked victims. In 1999, the Italian police raided a nightclub, arrested the owners and rescued 12 women who had been forced into prostitution. The victims indicated in interviews with the IOM that most of them were beaten into submission, raped, forced to sleep with their 'owners' and their owners' friends. Some of the victims had been sold more than once. They had to pay their new owners large sums anytime they were sold. This meant increased debts for them. Those who managed to pay their 'owners' in full were forced to forfeit $50 \%$ of their earnings and an additional $10 \%$ for housing. These were the lucky ones (IOM News, 2000). In the film The Day My God Died, children some of whom were only 7 years old, were trafficked from neighboring towns into Bombay, India where they were auctioned at a slave-trading market. Some of them children were drugged before their journeys. In another documentary, Sacrifice by Ellen Bruno, the children whose ages were not disclosed but looked younger than ten, were brainwashed into feeling sorry for their parents or guardians and thus believing that it was going to be beneficial and for that matter rational for them to leave their home country of Burma for Thailand where there would be plenty of money. 
Debt Bondage. The last source of contemporary slavery is debt bondage. Debt bondage pervades all the forms of contemporary slavery. Most of the slaves found in the manufacturing industries in India suffer in bondage. There are estimated 15 million bonded slaves in India alone (Tucker, 1997). Some of them are as young as five, and may work their entire lives to repay meager sums of money that their families borrowed for food or for other emergencies (Tucker, 1997). It is not unusual for the bonded slaves to pass the debts unto their children or their children's children (Tucker, 1997; Mishra, 2000; Burra, 1995). When the bonded slave is incapacitated through illness or old age, their young sons or siblings may be forced to take their place in bondage. Where bondage occurs through migration and trafficking, the victims could owe the traffickers or their agents US $\$ 30$ to US $\$ 40,000$ (France, 2000).

\section{Types of the Slavery of the New Labor Relations}

In the following sub-sections, three types of contemporary slavery that are defined as resulting from contemporary labor relations will be discussed. These are the domestic slavery, slaves who work on farms and in industry, and those who are found in prostitution.

\section{Domestic Slavery}

Domestic servants are known in Haiti as restavecs (i.e. "staying with"), and vidomegon in Benin (Declaration). In Ghana, they are referred to as maids, house-helps, house-girls or maidservants. Among the Akans of Ghana, the servant is known as an 'abaawa', which means servant. It is no longer used, at least not in the open, because it is considered derogatory. Using existing research, this section discusses the number of 
hours that the domestic slave works, the slave-like conditions under which they work and the sort of physical abuses that they have to endure for as long as they remain in servitude.

Two definitions of the provision of services within the household are examined. The first is one provided by the ILO. The ILO refers to this category of contemporary child slavery as domestic child labor and defines it as "children working in an employer's house with or without a wage" (ILO, 2001b: vi). This definition overlooks the working conditions of the children and thus neglects the possible enslavement of the so called workers. The second, which focuses on the service itself, is a definition by Bee, (1998). She defines domestic services as "the many and varied types of work required to complete those duties pertaining to the maintenance, functioning, and day-to-day running of the household, particularly when performed by employed labor" (Bee, 1998: 1).

This thesis goes beyond these definitions to distinguish between the domestic servant or worker and the domestic slave. This distinction is relevant because domestic work in itself is not slavery. The domestic worker or servant, for the purpose of this thesis, is defined as one who works for pay and does not qualify as a slave because of the legitimacy of the relationship between her and the employing household. This legitimacy lies in the high probability that the worker's basic rights may not have been violated. Moreover the domestic worker exercises control over the ultimate decision to remain a service provider in the specific household. 


\section{Characteristics and Gender of the Domestic Slave}

Domestic slaves, unlike domestic servants or workers, are very young, usually below the minimum ages allowed in the respective countries for children to be admitted into employment. In Dhaka, Bangladesh, $20 \%$ of the domestic workers are aged between 5 and 10 years (UNICEF, 1999). It is estimated that $80 \%$ of the girls who work in domestic servitude are aged 10 and 14 years (ibid.). Other research shows that $16 \%$ of domestic 'workers' in Togo are 10 years or less, 50\% under 14 and $65 \%$ under 15 years (ibid). Approximately $34 \%$ of the domestic servants in Uruguay started work before they were 14 years, while in Venezuela, 25\% of them are less than 10 years (ibid.). According to an ILO-IPEC report on Nepalese employers are more attracted to younger domestic servants because their wages, if ever paid at all, tend to be small (ILO, 2001b). This makes it easy for employers to move these servants to slave status.

Most of the domestic servants studied were either never enrolled in school or dropouts. According to the ILO, this stems from the fact that most of them are taken from their parents at a very young age. In Nepal, $18 \%$ of the domestic slaves interviewed could neither read nor write (ILO, 2001b). An estimated $10 \%$ of them could only write their names, while a little over $53 \%$ had received primary education. Nearly $18 \%$ were educated beyond the primary school. In all, only .3 percent of the entire sample had some secondary education. This report indicated further that domestic male domestic slaves were more educated than the girls, this being a reflection of the literacy rates in the wider society.

Domestic slavery is gendered. It is estimated that $90 \%$ of domestic workers around the world are girls (UNICEF 1999; UNCHR, 2002). The higher incidence of girls 
in domestic slavery than boys could be explained both in terms of factors emanating from the supplying family, and factors associated with the employing or receiving households. The factors influencing the giving family to send their daughter instead of the son are traditional, economic and patriarchal. It is traditionally believed in some cultures that girls would end up as housewives, childcare and homemakers, and thus do not need to receive formal education (Mikay, 1997; UNICEF, 1999). Moreover, parents consider their daughters to be thriftier than boys because of a general notion than girls neither smoke nor drink. They are thus made to work while the resources are deployed into educating the boys (ILO, 2002c).

Patriarchal influences on the exploitation of female children's labor in domestic servitude vary according to culture. Almost every country in which the UNICEF conducted a research on child domestic slaves had a cultural reason for the dominance of girls in household servitude. In Togo where $95 \%$ of the child domestic servants are girls, it is strategic to use the girls' income to support the education of their brothers. In Bangladesh, restricting the girls to household chores is considered a means to protect them, while in Nepal, girls are preferred to boys in domestic servitude because they are considered more submissive and are less likely to run away (UNICEF, 1999).

There are exceptions to these observations though. In Haiti, both boys and girls stand almost the same risk of being employed into household slavery, if they come from poor homes (Cadet, 1998). Skin color, although not generally so significant in the determination of contemporary slavery, does play a role in the enslavement of children in Haiti (ibid). According to Cadet (1998), children of light skin color are considered elite and hardly ever become domestic slaves. A restavec himself, Cadet had often been 
treated like an elite child because of his skin color. He states that poor children in Haiti had dark skin and appeared dusty and malnourished (ibid.).

\section{How Many Domestic Slaves}

It is not statistically known how many girls and boys have been enslaved in domestic servitude. A couple of reasons are responsible for this. First, they are engaged in the informal sector, which lacks adequate record keeping (UNICEF, 1999). The second factor explaining the obscurity of domestic child slaves is the tendency for them to be considered a household member rather than an employee or slave because of their location within the household (UNICEF, 1999).

It is estimated that there are about 250,000 domestic slaves in Haiti alone (Cadet, 1998; UNICEF, 1999). In Dhaka, Bangladesh, there are as many as 300,000 child domestic slaves while Jakarta, the capital of Indonesia has an estimated 700,000 (UNICEF, 1999). There are approximately 150,000 child domestic slaves in Lima, Peru, and 766,000 in the Philippines (ibid.). In Kathmandu, there are an estimated 60,000 child domestic servants, while there are approximately 55,655 child domestic workers. The ILO report on Kathmandu's domestic servants shows that it is parents who give their children away into domestic servitude (ILO, 2001b). While $46 \%$ of their respondents indicated that their relatives were responsible for enrolling them into domestic servitude, $86 \%$ of them agreed that their parents advised that they accepted such a job (ibid.).

\section{Hours Worked, Responsibilities and other Expectations}

Child domestic slaves around the world work 10-18 hours a day, usually throughout the week and often without pay (UNICEF 1999; UNCHR, 2002). In 
Bangkok, they work 12 to 15 hours a day (ILO, 2002c). On average, domestic slaves in Kathmandu work 7 to 18 hours daily (ILO, 2001b). More than two-thirds of them work 14 hours a day. They work on holidays and over the weekends. Their day begins around 5 a.m. each morning. They spend their entire time in their employer's households and when they have no chores to do, they still may not be allowed to leave the house (UNCEF, 1999). Their responsibilities include cleaning, laundry, food preparation, cooking, shopping and looking after young children.

Media reports often appear about the treatment meted out to contemporary domestic slaves. France (2000) reports of a Cameroon girl who worked 16 hours a day for over four years without pay in the United States. When her employers were sending her to the United States she was promised a formal education, but this was never to be until she was freed and rehabilitated after four years. Another victim was smuggled into the United States at the age of 17 (France, 2000). For five years, she worked 16 hours a day, serving a family of five. A 10 year old Benin girl was given away by her parents in exchange for money when she was only seven years old. She lived and worked as a domestic slave in Abidjan, the capital of Cote d'Ivoire for three years (Time, 2001). She was never paid for the services.

The domestic slave is discriminated against in the use of household space. Cadet (1998) kept his beddings in the kitchen when he lived as a restavec in Haiti. These beddings were made up of his madame's old clothes. Many a maidservant in Ghana sleeps on similar beddings. Cadet usually ate different food, and was not allowed to sit in the living room with the rest of the family. If Cadet ever wanted to watch the television in the nights after his chores were done, he would usually stand on a stone with his 
restavec neighbors and peep through a window. Bee (1998) observes in her research on Peruvian domestic workers that they slept in different quarters. Although she did not categorize these subjects as slaves, using different space within the household is characteristic of most of the domestic slaves.

\section{$\underline{\text { Sexual and other forms of Abuses }}$}

Newspaper reports indicate that domestic servants may either live with relatives or non-relatives. However, living with relatives does not guarantee the child's freedom from abuse. It does not change the significant fact that the maid is a slave and thus occupies an inferior position within the household structure. It is from this position that the 7-year-old or so begins to lose her childhood. It has been emphasized that domestic slaves suffer physical abuse, some of which are sexual. It is estimated that $60 \%$ of Peruvian men who grew up with domestic slaves had their first sexual encounter with the victims of domestic slavery (The UNCHR, 2002, UNICEF, 1999; Bee, 1998), while 80\% of the domestic workers in Fiji are also exploited sexually (UNCHR, 2002). In Rwanda, most of the domestic servants suffer sexual abuse while they are still young (UNCHR, 2002). A majority of Ethiopian trafficked women and girls work as domestic maids in Lebanon and Bahrain and they also reported cases of rape, physical abuse, nonpayment of salaries and debt-bondage (International Organization for Migration, 2000).

\section{Contemporary Slavery in Agriculture, Industry and Other Occupations}

This section discusses child slavery in agriculture and industry. The majority of child slaves in these industries are trafficked. These victims work on cocoa farms in parts of West Africa and in the tea and coffee plantations and industries in East Africa. In 
India, they are employed in the manufacturing of beedi (cigarette), matches, fireworks and explosives, glass and carpets. They are found in glass polishing, brassware making and mining industries respectively. None of these could be categorized as safe enough for the young children. Like the domestic slaves, the slaves under this category are concentrated in the informal sectors. In India for example, children aged between six and 14 years make up the vast majority of the child workers who are engaged in the unorganized sector (Mishra, 2000).

Characteristics of the Child Slaves in Agriculture and Industry

Victims in this category are aged between 3 and 17 years old. But like all cases of child labor exploitation and slavery, the ages vary according to country and occupation. In Cote d'Ivoire, the victims are aged between 9 and 15 years ((Sudarsan $\&$ Raghavan, 2001). In India, they could be as young as three years, depending on the industry and the location of the occupation (Mishra, 2000).

Most of the child slaves in these sectors were either never enrolled in formal education or dropped out before they completed primary six. The current rates of nonschool going children tend to be relatively high especially for girls although dropout rates are declining (Mishra, 2000). Approximately $86 \%$ of all rural child workers were illiterate, while $94 \%$ of all female child workers in India are illiterate. An estimated $60 \%$ of all children who are not enrolled in schools are girls. Mishra (2000) argues that drop out rates was also high among the girls. Approximately $40 \%$ of them - the girls - would usually remain in school until class five, $18 \%$ would continue till the 8 th grade, $9 \%$ to the 9 th grade while only $1 \%$ would complete the $12^{\text {th }}$ grade. 
As is shown in the appendix on trafficking, child slaves on plantations in West Africa are usually trafficked. From Benin, children are trafficked into Nigeria, Ghana and the Gabon for exploitation on farms (US State Department, 2001). From Ghana, the children are trafficked for farm labor in the Cote d'Ivoire, Togo and Nigeria (US State Department, 2001). In April 2001, a Nigerian registered ship, MV Etiremo was not allowed to dock in the Gabon, Cameroon and Benin. According to the $\mathrm{BBC}^{2}$ and Time (2001), the ship carried about 200 children that were suspected to be slaves. It was anticipated that most of them would have ended up on cocoa farms as laborers, or in the case of the girls, as sex slaves.

\section{Risks and Experiences}

Slaves under this category work from dawn till dusk and are subjected to violent physical abuses. Child slaves in industry and agriculture sustain injuries from beatings and sharp equipment such as machetes. They inhale dangerous pesticides and other chemicals, and in some cases, encounter deadly motor accidents (Mishra, 2000; Mikay, 1997; Burra, 1995). In the lock-making factories of India, child workers inhale emery powder, toxic substances and metal dust. They are at risk of being injured by metals that accidentally drop down and are exposed to dangerous chemicals that include acids (Burra, 1995; Mishra, 2000). Some respondents of the ILO rapid assessment in Tanzania indicated that they often suffered from sharp knife injuries. From beedi rolling to glass polishing, underage child slaves in India suffer many respiratory diseases (Mishra, 2000).

\footnotetext{
${ }^{2}$ The General News of April 16, www.ghanaweb.com.
} 


\section{Prostitution}

There have been arguments as to whether prostitution should be categorized as slavery or a profession (Kempadoo and Doezema, 1998). Some scholars employ the forced-voluntary dichotomy to determine whether or not a particular sexual relationship is considered slavery. Not having been forced into it means volunteering one's participation. One must consent. But as emphasized earlier, children are not mature and knowledgeable enough to give their consent. Consequently, Barry and her Coalition Against Trafficking in Women (CATW) define prostitution as a form of sexual exploitation that has the same magnitude as rape, female genital mutilation, incest and battering (Barry, 1984; Kemopadoo and Doezema, 1998). Sexual exploitation is defined in this context as "a practice by which women are sexually subjugated through abuse of women's sexuality and or violation of physical integrity as a means of achieving power and domination including gratification, financial gain, advancement" (Doezema 1998: $35)$.

Barry and other abolitionists do not only perceive prostitution as a form of sexual exploitation, but slavery as well. The architects of sexual slavery carry out their exploitation of the vulnerable women as an organized venture or on individual bases. When organized, it “is a highly profitable business that merchandises women's bodies to brothels and harems around the world" (Barry, 1984: 39). When practiced individually, "it is carried out by pimps whose lifestyle and expensive habits are supported by one or two women whom they brutally force to sell their bodies for his profit" (ibid.).

It is not disputable that some prostitutes voluntarily chose to go into that profession. Moreover, some sex workers do not wish to be sympathized or categorized 
this way - they would want to be given the same positive recognition as other workers (Kempadoo and Doezma, 1998). Nevertheless, research shows that childhood traumas that some of them experienced, and control by organized criminals, led them into prostitution (Barry, 1984). Stepfathers and uncles are usually the main offenders. Other victims would run away from home and find refuge in the street or in the company of older friends, would-be pimps who would introduce them into prostitution (ibid). The prostitutes' daily proceeds go to these pimps, and they are physically abused if they refuse to hand the monies to them or to report to work. The documentary "The Day my God Died" shows Bombay's sex slaves being kidnapped and trafficked from neighboring towns and villages. They were beaten, some to death, burnt with cigarettes and were threatened to be buried alive when they refused to have sex with patrons of the brothels to which they were sold. The ordeal was so grave two sisters hung themselves when they were brought to one of the brothels.

Apart from the loss of free will and the violent threats and abuse the sexual slave endures, the ages at which they are enrolled makes it impossible for some of them to have voluntarily entered this profession. In Nepal and Bangladesh, children are sent away, sometimes at the age of six, from their families to work in brothels that earn them $\$ 6$ per sexual encounter (Lukas, 1996). 12-year-old sex slaves in Bombay are paid 50 cents for half an hour of an encounter (ibid.). These children are sometimes held in cages. In Amsterdam, show-window prostitutes are under 14 (ibid.). There are approximately 200,000 child prostitutes in Thailand, 60000 in the Philippines, 250000 in Brazil and over 200,000 in the United States (ibid.). These are victims of contemporary child 
slavery. In "The Day my God Died," some of girls were as young as seven. In Jamaica, there are underage children, some 10 years of age who work as adult prostitutes.

\section{Chapter Summary and Conclusion}

This chapter focuses on three main forms of contemporary child slavery, namely domestic servitude, prostitution and slavery in industry and agriculture. Contemporary slavery is categorized into two forms: cultural forms of contemporary slavery and slavery of the new labor relations. Based on existing literature, evidence is presented that child slavery and child labor exploitation have become a universal phenomenon, concentrated in low-income countries but available for exploitation by the advanced world. Child slaves, whether working as domestic servant, working on plantations or as prostitutes in brothels or massage parlors are more preferred to adults. The literature shows that employers prefer them to adults because their nimble fingers could handle certain minute pieces of work better. Additionally, they are more vulnerable and easier to control by factory owners, supervisors and managers. Adult workers and supervisors do not feel intimidated by their presence. Children therefore constitute the highest proportion of the victims In domestic servitude, prostitution or sexual exploitation and abuses on farms, manufacturing industries and in the military today. 


\section{CHAPTER FIVE}

\section{SUMMARY AND CONCLUSIONS}

Following Kopytoff's theory on the culturally informed biographies of commodities, discovering the experiences of contemporary slaves, if they existed at all is the focal point of this thesis. Existing definitions are examined and compared with the experiences of young children who perform activities that could be considered slavery or otherwise. A major conclusion from these analyses is that a new kind of slavery exists. This slavery, although discernible from all other forms of forced servitude, shares certain basic attributes with them. These are powerlessness and the loss of free will, control through violent threats and long hours of work without enough compensation, if any at all. In addition to these attributes, the exploitation of children's labor was considered a special case so that other factors, such as the age of the victims and the violation of their fundamental human rights may produce conditions of slavery.

The underlying factor in any kind of slavery is the loss of free will. This is the inability for one to free oneself or to refuse participation in the prescribed activity or to free oneself from it later. Any attempts on the victims' part to free themselves would be greeted with threats to their lives and physical abuses. Some such abuses have been deadly. On the other hand, any conditions that entail nothing more than low wages that are characteristic of most Third World employment situations are perceived as labor exploitation rather than slavery. When children's labor is exploited, they are more likely to be defined as slaves because of their vulnerability. Underage children are perceived as immature and least knowledgeable. But they, like everyone else, must give adequate 
consent prior to their engagement in any employment. However, consent requires knowledge and maturity (Barry, 1984). Given their immaturity and lack of knowledge, which means that they cannot give consent to work under any conditions, underage children are not only exploited, but enslaved.

This thesis employed the UN's Convention on the Rights of the Child to define children as all persons below 18 years of age, unless otherwise specified within the legal statutes of specific countries. This caveat applies because the minimum age for admission into employment varies between 12 and 15 years in individual countries. Thus, persons who were admitted into employment when they were at least 12 years are not as likely as younger children to be categorized as slaves. If a 15-year-old were denied formal education and subjected to long hours of work without pay, they could be qualified as a contemporary slave. Nevertheless, to be categorized as a contemporary slave, the victims must have been forced into employment, and stripped of their power while controlled through violent threats.

Children who are 15 years of age or younger are not considered mature and knowledgeable enough to volunteer participation in any field. In fact UNICEF asserts that all children are immature and need protection, being unable to give consent to any employment as noted earlier. Hence, unless admitted into those occupations that are allowed at the children's age, they are automatically facing labor exploitation. If they are able to be in control, receive remuneration proportionate to their work, and able to remain in and participate successfully in school, then they are not exploited at all. Their work is considered positive. Furthermore, child workers who are not exploited must not work long hours, and the hours worked should not interfere with their academic work. 
It is more likely for children who start work for the first time when they are 15 years or older to qualify as child workers. At that age, they may have acquired at least a basic education. Children who start work below that age are the least mature, and knowledgeable and thus cannot volunteer their participation in the fields they find themselves in - they are extremely vulnerable and powerless, and are more likely to be exploited under slavery conditions. Underage children are engaged in domestic servitude, farm labor and prostitution. They cannot on their own decide to work in these fields. They may have been kidnapped, sold and or trafficked without consent. In some cases, their labor may have been exchanged for loans and for as long as their families remain indebted to the creditors, they would remain bonded. But according to the UNICEF's Convention on the Rights of the Child, children are not properties of their families so that their childhood must not be sacrificed for their families' survival.

It is routine for some children to perform household chores even before they are turned into slaves. Nevertheless, performing household chores while still living and sharing the love of one's family is not comparable to working long hours in a different home. It is also possible for children who are exploited on cocoa, coffee and tea plantations to have worked to assist with their families' farms. Here again, the love and support of one's family could have lessened the pain that comes with staying a couple of hours on family farms. In view of this, children who work for other families may lose their childhood and may forever live with horrible memories that would negatively affect their self-confidence and personalities. Their integration into society during adulthood may also be problematic. Their lack of literacy, and, in some cases numeracy, may affect their future employability. 
Child slavery thus involves the underpayment or no complete lack of payment for services rendered, in addition to the loss of free will, and the experience of control through violent threats. Victims are usually physically and/or sexually abused, refused food, and constantly punished when they refuse to perform their supposed duties while having been made powerless through all the above. Moreover, it is usually difficult for contemporary slaves to leave servitude. Their lives are sometimes threatened if they attempt to escape. To conclude, contemporary child slavery refers to the coercive engagement of children's labor under conditions that conflict with the victim's cultural practices, compels them to work long hours without proportionate remuneration, denies them the free will to volunteer participation in the said occupations and deprives them of their fundamental rights as human beings, more specifically as growing children who need love, care and protection. Repressive child labor is culturally and temporally situated, nevertheless, when the child's work experiences bear the slavery characteristics as have been outlined in this thesis, it is proper to consider the overall welfare of the child rather than the implications of cultural relativity.

Hopefully, the issues raised in this thesis will sensitize scholars and policy makers to the incomplete understanding of children's labor exploitation. Child labor does not mean repressive child labor. The ILO has indicated that child labor does not have to be negative. Given the many conventions and treaties that are geared towards the elimination and prevention of contemporary slavery, it is not questionable that the plight of children forms a part of important debates within these international agencies. Nevertheless, a lack of understanding of what is meant by children's labor exploitation may obstruct any attempts to discuss the children's plight. 


\section{Limitations of the Thesis}

This thesis relied on secondary sources of data for its analyses. Given the paucity of research on contemporary slavery, the literature was supplemented with newspaper reports that are yet to be verified through systematic research. The bulk of what is considered as research on contemporary slavery was actually conducted with a focus on child labor. Researchers were found to generally not be interested in investigating the existence of child slavery. They focused on child labor even though, as this thesis argues, the concept of 'child labor' as it exists in the literature is ambiguous. In view of this, inferences that were made from their reports may not represent what may have been observed. Additionally, the use of newspaper reports to back the arguments made in this thesis placed a limitation on the verifiability of these analyses.

\section{$\underline{\text { Recommendations }}$}

As children taken away from their parents and placed in servitude during their formative ages, contemporary child slaves indisputably lose their childhood. The maidservant, for instance, learns in the formative years of her life that she is different and less important than the people around her. The loss of her personality, self-esteem and childhood begins soon after realizing that although she deems herself capable of doing well in school, she is not 'qualified' because of her out-group position. As this thesis showed, some prostitutes suffered sexual abuse when they were still young. Child slaves in the manufacturing and agricultural sectors also go through experiences that may impede their integration into societies. Theirs is a sort of semi-socialization. This is because the love and care that usually come with the processes through which children 
become part of their cultural communities are non-existent when child slaves are resocialized into slave statuses. They undergo psychological trauma which becomes internalized. As adults, they may be antisocial and thus deviate from social norms. They may not be economically independent, because of their lack of formal education. This would exacerbate their poor conditions because their past statuses would be reproduced. They may not be able to positively influence the economic statuses of the generations that would come after them. The vicious cycle of poverty thus continues.

It is in view of the above that the international community has launched various projects and researches to eliminate child labor exploitation in general. This thesis acknowledges the need for these programs and recommends that academia collaborate with the United Nations and its subsidiaries, as well as non-governmental and international non-governmental organizations to help improve the situation of underprivileged children around the world. Given the assertion that historical stages experience a type of slavery that is unique and spatially and temporally defined, the thesis predicts that exploitation of the vulnerable in societies under slavery conditions will always exist in societies. What needs to be done, therefore, is the institution of proactive measures that would help improve the working conditions of the underdog while reducing the incidence of slavery. The role of academia in whatever measures need to be established is, indispensable. Scholars could augment efforts of the international community through research projects that would sensitize stakeholders and various communities to the plight of the children. Ambiguous conceptualization needs to be clarified as has been attempted in this thesis. 
Any framework developed about children's labor exploitation and slavery must not be allowed to sit idle on the shelves. It is imperative that such knowledge is disseminated through different means so that the general public can be kept constantly informed about the continued existence of slavery. They must be kept informed about the nature of the new slavery. This requires extensive education. This way, they can be alerted to the problem and thus made part of the efforts to solve problems of child labor exploitation. Such education should not be limited to informal channels of education such as the media, but be integrated into the regular curriculum of schools.

According to the Concern for Working Children (2001), India's children complained about their isolation from the establishment of policies and treaties that focused on children's rights and their problems. In a speech delivered on its behalf, the NGO Forum of Working Children, an organization that is made up of 21 working children from movements and organizations in Latin America, Africa and Asia at a 1997 Ministerial Conference, argued, among other things, that children should be consulted and involved in meetings, conferences and processes of making legislation that focus on children (Concern for Working Children, 2001). In their opinion, children want to be allowed equal participation with adults at international conferences and meetings. By making child labor exploitation and slavery an open issue for debate even among children, diversity in the approaches to solving problems of contemporary slavery may not be the only outcome. It is to be hoped that these efforts would, as a by-product, boost the self-esteem of the exploited children, letting them know there is some love and care for them in their situation. 
Finally, it is recommended that the euphemistic use of child labor for

circumstances that are indisputably slavery be stopped. As the thesis has argued, this can misguide and distort research findings. It is important that research completed by academia and agencies advocating the freedom and the rights of children be informed by a succinct distinction between child labor and child slavery. No matter the extent of labor exploitation, child slavery is distinguishable from all other forms of child abuse. Any situation that is described as child slavery or child labor must involve the use of children's mental and physical energies in production and or services. This way, practices such as female genital mutilation would not be confused with child slavery. When the exploitation entails underpayment of wages, it is recommended that research perceives that as merely repressive children's labor. This does not overrule the fact that non-slave-like repressive labor could place impediments in the child's growth. It remains important that the continued clarification of definition and evolution of useful framework to discuss slavery and child slavery in particular may not be forgotten. 


\section{Bibliography}

Accra Mail. (2001). Domestic servants escape through Aflao border. (2001) $<$ www.africaonline.com.gh/accramail >. 2001, June 21.

Amponsah, O. (2001). The Trokosi: Religious Slavery in Ghana. $<$ http://www.antislavery.org/global/ghana>. 2003, April 2.

Apollo R. (2001). African Women and Children: Crises Response. London: Praeger.

Archer, L. J. (ed.). (1988). Slavery and Other Forms of Unfree Labor. New York: Routledge.

Bales, K. (2000). New Slavery. California: ABC-CLIO, Inc.

Bales, K. (1999). Disposable People: New Slavery in the Global Economy. California: University of California Press.

Barry, K. (1984). Female Sexual Slavery. New York: New York University Press.

Bee, E. (1998). The Other Side of the Kitchen Door: Domestic Service in Lima, Peru. M.A. thesis, Department of Sociology and Anthropology, Florida International University, Miami.

Blagbrough, J \& Glynn, E. (1999). Child domestic workers: characteristics of the modern slave and approaches to ending such exploitation. Childhood 6(1).

Burra, N. (1995). Born to Work: Child Labour in India. Delhi: Oxford University Press.

Bush, M. L. (2000). Servitude in Modern Times. Cambridge: Polity Press.

Cadet, Jean-Robert (1998). Restavec: from Haitian Slaver Child to Middle-Class American. Texas: University of Texas Press.

Chase-Dunn, C. Thomas D. Hall. (1997). Rise and Demise: Comparing World Systems. Colorado: Westveiw Press.

Chidey, J. (1996). A fight to save the children: activitists battle the sexual exploitation of the kids. Maclean's, 109 (36), 20-22.

Child labor on the increase. (1996) African Business, 6.

Concerned for Working Children. (2001). Working Children's Report. $<$ http://www.workingchild.org/>. 2002, May 22. 
Cotton, S. (1998). Silent Terror: A Journey into Contemporary African Slavery. NY: Writers and Readers Publishing, Inc.

Cox, K. E. (1999). The inevitability of nimble fingers? Law, development, and child labor. Vanderbilt Journal of Transnational Law, 32 (1), 115(1).

Davis, D. B. (1984). Slavery and Human Progress. New York, Oxford University Press.

Donkor, K. (1997). Structural Adjustment and Mass Poverty in Ghana. Aldershot: Ashgate Publishing Ltd.

Durdon, J. (1988). Slavery as a Punishment in Roman Criminal Law. In Archer L. J. (Ed.). (1988). Slavery and Other Forms of Unfree Labor. New York: Routledge.

ECPAT: End Child Prostitution, Child Pornography and Trafficking of children for sexual purposes. (1999) WIN News, 25 (1) 42.

ECM. (2002). About the Trokosi Slaves. $<$ http://www.thinkwow.com/slavechild/>. 2003, April 2.

Engerman, S., Drescher, S., Paquette, R. (eds). (2001). Slavery. Oxford: Oxford University Press.

Equality Now. (2002). Slavery in Ghana: the Trokosi Tradition. < http://www.sossexisme.org/English/slavery.htm>. 2003, April 2.

France, D. (2000). Slavery's new face. Newsweek, 118 (6255), 84-89.

French, H.W. (1997). The ritual slaves of Ghana: young and female. New York Times CXLVI, 50(678), A1.

From the front lines - return assistance in the fight against migrant trafficking. (March, 2000). IOM News, 8.

Garnsey P. (1996). Ideas of Slavery from Aristotle to Augustine. New York: Cambridge University Press.

Gladwin, C. (ed). (1991). Structural Adjustment and African Women. Florida: University of Florida Press.

Goheen, M. (1991). The ideology and political economy of gender: women and land in Nso, Cameroon. In Gladwin C. (ed). (1991). Structural Adjustment and African Women. Florida: University of Florida Press. 
Grosfoguel R. and Cervantes-Rodriquez, A. M. (2002). The Modern/Colonial/Capitalist World-System in the Twentieth Century: Global Processes, Antisystemic Movements, and the Geopolitics of Knowledge. Connecticut: Preager Publishers.

Human Rights Watch Children's Right Project (1996). The Small Hands of Slavery: Bonded Child Labor in India. New York: Human rights Watch.

Innocenti Research Center (Undated). Data Base on Child Labour in India: An Assessment with Respect to Nature of Data, Period and Uses. India: Thorat, S.

Innocenti Research Center (2002). Child Work in Cote d'Ivoire. India: Francavilla, G., Lyon, $\mathrm{S}$.

ILO - International Programme on the Elimination of Child Labour (2002c). Thailand Child Domestic Workers: A Rapid Assessment. Geneva: Phlainoi, N.

International Organization for Migration. (2000a). Trafficking in Nigerian Women to work as prostitutes in Europe. Trafficking in Migrants: Quarterly Bulletin, $20,4$.

International Organization for Migration. (2000b). Information campaigns against trafficking. Trafficking in Migrants: Quarterly Bulletin, $20,1$.

International Organization for Migration. (2000c). Ethiopian women trafficked to the Arab countries. Trafficking in Migrants: Quarterly Bulletin, 20 (3).

International Organization for Migration. (2000c). Southern Asian Convention for Combating trafficking in Women and Children. Trafficking in Migrants: Quarterly Bulletin, 20, 3 .

International Labor Organization. (2001a). Stopping Forced Labor: Global Report under the Follow-up to the ILO Fundamental Principles and Rights at Work. Geneva: International Labor Office.

ILO. (2001b). Nepal Situation of Child Laborers in Kathmandu: A Rapid Assessment. Geneva: Sharma, S; Thakurathi, M; Sapkota, K.; Devkota, B.; and Rimal, B.

ILO. (2001c). Tanzania - Children in Prostitution: a Rapid Assessment. Geneva: Kamala, E.; Lusinde, E.; Millinga, J.; Mwaitula, J.

ILO (2002a). IPEC Action against Child Labor: Progress and Future Priorities. Geneva: International Labor Organization.

ILO. (2002b). Tanzania - Child Labour in the Informal Sector: A Rapid Assessment. Geneva: Kadonya C., Madihi M., Mtwana, S. 
International Labor Organization and Inter-Parliamentary Union. (2002). Eliminating the Worst Forms of Child Labor: A Practical Guide to ILO Convention 182. Geneva: ILO.

IOM News. (2000). Women trafficked to Kosovo. 8.

Kempadoo K. \& Doezema J. (eds) 1998). Global Sex Workers: Rights, Resistance, and Redefinition. New York: Routledge.

Kimaryo, M. and Pouwels, R. (1999). An African perspective: Child domestic workers in Tanzania. Child Workers in Asia 15 2, May-August: 26-28.

Kopytoff, I. (1986). The cultural biography of things: commoditization as process. In Appadurai A (ed) (1986). The Social Life of Things: Commodities in Cultural Perspective. United Kingdom: Cambridge University Press.

Laguerre, M. S. (1994). Headquarters and subsidiaries: Haitian immigrant family households in New York City. In Taylor, R. L. (1994). Minority families in America: An introduction: a multicultural perspective. New Jersey, Prentice Hall, Inc.

Lees, C. (1998). A burgeoning slave trade. World Press Review, 45(1), 40(1).

Leys, C. (1996). The Rise and Fall of Development Theories. Indiana: Indiana University Press.

Levine, R. (2003). Free the Trokosi. $<\underline{\text { http://www.freshangles.com/realtime/world/articles/20.htmll }>2003, ~ A p r i l ~} 2$.

Lukas E. (1996). Saving the Children. National Review, 48 (24) 30-31.

Macmunn, G. (1974). Slavery through the Ages.

Meltzer, M. (1980). All times, All Peoples: A World History of Slavery. New York: Harper \& Row, Publishers.

Mishra, L. (2000). Child Labour in India. New York: Oxford University Press.

Mikay, E. (1997). An economic essential? The Middle East, 272, 38-40.

Niagia, S. (2002). Children Forced to Atone for the Sins of Parents. $<$ http://www.dispatch.co.za/2000/03/16/features/KIDS.HTM $>$. 2003, April 2. 
Orhin, I. G. (2001). Ghanaians Asked to Condemn Trokosi.

$<$ http://www.ghanaweb.com/GhanaHomePage/NewsArchive/artikel.php?ID=136 51> 2001, February 21.

Palmie, S. (Ed.). (1995). Slave Cultures and the Cultures of Slavery. Knoxville: The University of Tennessee Press.

Patterson, O. (1982). Slavery and Social Death: a comparative study. Massachusettes: Harvard University Press.

Patterson, O. (1967). The Sociology of Slavery. Great Britain: Cox and Wyman Ltd.

Porter, K. A. (1999). An anthropological defense of child labor. The Chronicle of Higher Education, 46, (13), B11(1).

Puebla Process: Focus on Trafficking in Central America. (1997). International Organization for Migration News, $4,1$.

Rhode, D. (1999). City Worker Accused of Forcing Girl into Servitude. New York: The New Times.

Richard, A. O. (1999). International Trafficking in Women to the United States: a Contemporary Manifestation of Slavery and Organized Crime. Virginia: Center for the Study of Intelligence.

Robson, E. (1996). Working girls and boys: children's contributions to household survival in West Africa. Geography, 18(4), 403(5).

Rone, J. (1995). Children in Sudan: Slaves, street Children and Child Soldiers. New York: Human Rights Watch.

Rota, A. (1997). Brazil and UNICEF join to end child prostitution. UN Chronicle, 34 (4) 56-57.

Salter, W. (1997). Are any domestic helpers employed in your household? Child Workers in Asia 13 1:26-27.

Sawyer, R. (1988). Childhood Enslaved. London: Routledge.

Seabrook, J. (2000). Child workers, the shifting debate. Race and Class, 42 (2) 80.

Shoishab. (1997). Child domestics in Dhaka, Bangladesh. Child Workers in Asia 13 1:46. 
SLIMG Sri Lanka. (1997). Live-in Servants in Sri Lanka. Child Workers in Asia 13 1:1416.

Stark, O. (1991). The Migration of Labor. Massachusetts: B. Blackwell.

Stumpf, E. S. (1982). Socrates to Sartre: A History of Philosophy. New York: McGrawHill Book Company.

Sunoo, B. P. (2000). Caution: children at work. Workforce, 79 (9), 44.

Time. (2001). An awful human trade: in West Africa, an alleged slave-ship snafu reflects the trauma of an ongoing business of marketing children as forced labor. 157, (17) 40 .

Tucker L. (1997). The small hands of slavery: India's bonded child laborers and the World Bank. Multinational Monitor, 18 (1-2), 17-19.

UNICEF. (1999). The Innocenti Digest. Florence: International Child Development Center.

UNICEF. (1998). Girls at work. New York: UNICEF.

United Nations Commission on Human Rights, (2002). The relationship between child domestic servitude and the sexual exploitation of children. $<$ http://www.antislavery.org/archive/submission/submission2002childlabour.htm>.

US State Department. (2001). Victims of Trafficking and Violence Protection Act, Trafficking in Persons Report 2000. $<$ http:/www.state.gov/www/global/human rights/1999 hrp report/preface.html $>$.

Van Gennep, Arnold (1960). The Rites of Passage. Translated by Monika B. Vizedom and Gabrielle L. Caffee. Chicago: The University of Chicago Press.

Verlett, M. (2000) Growing up; in Ghana: deregulation and the employment of children. The Exploited Child, Schlermer (ed). New York: Zed Books.

Xedia Systems Limited. (1999). Modern Slavery.

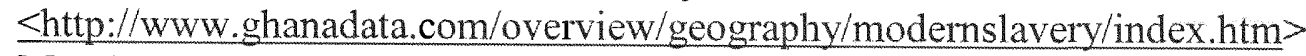
May 13, 2002. 
Details on Trafficking In Persons by Country.

Table Compiled for this Thesis from Data in

State Department Report on Trafficking

\begin{tabular}{|c|c|c|c|c|c|}
\hline Country & Role & Destination/Origin & $\begin{array}{l}\text { Who } \\
\text { Trafficked }\end{array}$ & Purpose & Comment \\
\hline Angola & $\begin{array}{l}\text { Internal } \\
\text { trafficking }\end{array}$ & & $\begin{array}{l}\text { Women and } \\
\text { children }\end{array}$ & $\begin{array}{l}\text { Forced labor, } \\
\text { sex slavery and } \\
\text { military services }\end{array}$ & $\begin{array}{l}\text { UNITA rebels } \\
\text { are responsible } \\
\text { for the victim's } \\
\text { abduction }\end{array}$ \\
\hline Bangladesh & Source & $\begin{array}{l}\text { India, Pakistan and } \\
\text { the Middle East }\end{array}$ & $\begin{array}{l}\text { Women and } \\
\text { children }\end{array}$ & $\begin{array}{l}\text { Women and } \\
\text { girls are used } \\
\text { for sexual } \\
\text { exploitation } \\
\text { while the boys } \\
\text { as camel } \\
\text { jockeys }\end{array}$ & $\begin{array}{l}\text { Government is } \\
\text { making } \\
\text { significant } \\
\text { effort to } \\
\text { combat } \\
\text { trafficking }\end{array}$ \\
\hline Benin & $\begin{array}{l}\text { Source, } \\
\text { destination } \\
\text { and transit }\end{array}$ & $\begin{array}{l}\text { From Benin to: } \\
\text { Ghana, Nigeria, and } \\
\text { Gabon } \\
\text { To Benin from: } \\
\text { Niger, Togo } \\
\text { Burkina Faso }\end{array}$ & Children & $\begin{array}{l}\text { Household } \\
\text { servitude, farm } \\
\text { labor and } \\
\text { prostitution both } \\
\text { domestically } \\
\text { and } \\
\text { internationally }\end{array}$ & $\begin{array}{l}\text { Benin is } \\
\text { participating in } \\
\text { UNICEF and } \\
\text { ILO projects to } \\
\text { combat } \\
\text { trafficking }\end{array}$ \\
\hline Brazil & $\begin{array}{l}\text { Source } \\
\text { country }\end{array}$ & $\begin{array}{l}\text { Europe, Japan, } \\
\text { Israel, US }\end{array}$ & $\begin{array}{l}\text { Women and } \\
\text { children }\end{array}$ & $\begin{array}{l}\text { Sexual } \\
\text { exploitation of } \\
\text { women and } \\
\text { children while } \\
\text { boys are } \\
\text { engaged on } \\
\text { local farms }\end{array}$ & $\begin{array}{l}\text { The } \\
\text { government is } \\
\text { making efforts } \\
\text { to combat } \\
\text { trafficking }\end{array}$ \\
\hline Bulgaria & $\begin{array}{l}\text { Source and } \\
\text { transit }\end{array}$ & $\begin{array}{l}\text { Transit from: } \\
\text { Romania, Moldova, } \\
\text { Russia, Ukraine, } \\
\text { Armenia, } \\
\text { Azerbaijan, } \\
\text { Georgia, } \\
\text { To: Macedonia, } \\
\text { Greece, Turkey, } \\
\text { Kosovo, Bosnia, } \\
\text { Italy, Poland, W. } \\
\text { Europe } \\
\end{array}$ & Women & $\begin{array}{l}\text { Sexual } \\
\text { exploitation }\end{array}$ & $\begin{array}{l}\text { Government is } \\
\text { making efforts } \\
\text { to combat } \\
\text { trafficking and } \\
\text { assists NGOs } \\
\text { engaging in } \\
\text { rehabilitating } \\
\text { victims. }\end{array}$ \\
\hline Burkina Faso & $\begin{array}{l}\text { Source, } \\
\text { transit, } \\
\text { destination }\end{array}$ & $\begin{array}{l}\text { From B. Faso: to } \\
\text { Europe, Ghana, } \\
\text { Cote D'Ivoire, } \\
\text { Nigeria, Germany } \\
\text { To B. Faso: Mali }\end{array}$ & $\begin{array}{l}\text { Women and } \\
\text { children }\end{array}$ & $\begin{array}{l}\text { Domestic } \\
\text { servitude, farm } \\
\text { labor and sexual } \\
\text { exploitation }\end{array}$ & $\begin{array}{l}\text { There are } \\
\text { constitutional } \\
\text { and legal codes } \\
\text { against } \\
\text { trafficking and } \\
\text { kidnapping }\end{array}$ \\
\hline
\end{tabular}




\begin{tabular}{|c|c|c|c|c|c|}
\hline Cambodia & $\begin{array}{l}\text { Source, } \\
\text { destination } \\
\text { and transit }\end{array}$ & $\begin{array}{l}\text { From Cambodia: to } \\
\text { Thailand } \\
\text { To Cambodia: from } \\
\text { Vietnam }\end{array}$ & $\begin{array}{l}\text { Men, women } \\
\text { and children }\end{array}$ & $\begin{array}{l}\text { Sexual } \\
\text { exploitation and } \\
\text { bonded labor } \\
\text { that include } \\
\text { street begging }\end{array}$ & $\begin{array}{l}\text { Government } \\
\text { has developed } \\
5 \text { year plan to } \\
\text { end child } \\
\text { sexual } \\
\text { exploitation }\end{array}$ \\
\hline Cameroon & $\begin{array}{l}\text { Source, } \\
\text { transit and } \\
\text { destination }\end{array}$ & $\begin{array}{l}\text { From Cameroon: to } \\
\text { West African } \\
\text { countries } \\
\text { To Cameroon from: } \\
\text { Burkina Faso, Cote } \\
\text { D'Ivoire, Ghana, } \\
\text { Mali, Nigeria, } \\
\text { Senegal, Togo } \\
\end{array}$ & Children & $\begin{array}{l}\text { Domestic } \\
\text { servitude, farm } \\
\text { labor and sexual } \\
\text { exploitation }\end{array}$ & $\begin{array}{l}\text { Cameroon is a } \\
\text { participant of } \\
\text { an ILO } \\
\text { trafficking } \\
\text { project }\end{array}$ \\
\hline China & $\begin{array}{l}\text { Source and } \\
\text { destination }\end{array}$ & $\begin{array}{l}\text { From China: to } \\
\text { Malaysia, Burma, } \\
\text { Japan, North } \\
\text { America, Australia, } \\
\text { Philippines, and } \\
\text { Taiwan. } \\
\text { To China: from }\end{array}$ & $\begin{array}{l}\text { Women, } \\
\text { men and } \\
\text { children }\end{array}$ & $\begin{array}{l}\text { Internal } \\
\text { trafficking } \\
\text { primarily to } \\
\text { provide lower- } \\
\text { middle income } \\
\text { farmers with } \\
\text { brides or sons, } \\
\text { in a few cases } \\
\text { for sexual } \\
\text { exploitation. } \\
\text { Internationally, } \\
\text { some victims } \\
\text { are sold into } \\
\text { forced labor and } \\
\text { prostitution } \\
\end{array}$ & $\begin{array}{l}\text { The law } \\
\text { prohibits } \\
\text { trafficking in } \\
\text { women. } \\
\text { Government } \\
\text { making } \\
\text { extensive } \\
\text { efforts to } \\
\text { combat all } \\
\text { forms of } \\
\text { trafficking }\end{array}$ \\
\hline Costa Rica & $\begin{array}{l}\text { Transit and } \\
\text { destination }\end{array}$ & $\begin{array}{l}\text { Transit from Asia to } \\
\text { US } \\
\text { To Costa Rica: from } \\
\text { Philippines, Africa, } \\
\text { Bolivia, China, } \\
\text { Colombia, Cuba, } \\
\text { Dominican } \\
\text { Republic, Middle } \\
\text { East }\end{array}$ & Girls & $\begin{array}{l}\text { Sexual } \\
\text { exploitation }\end{array}$ & $\begin{array}{l}\text { Criminal code } \\
\text { prohibits } \\
\text { trafficking in } \\
\text { women, } \\
\text { government } \\
\text { making efforts } \\
\text { to combat it }\end{array}$ \\
\hline $\begin{array}{l}\text { Cote } \\
\text { D'Ivoire }\end{array}$ & $\begin{array}{l}\text { Source and } \\
\text { destination }\end{array}$ & $\begin{array}{l}\text { From IC: to Africa, } \\
\text { Europe and the } \\
\text { Middle East } \\
\text { To IC: from Mali, } \\
\text { B. Faso, Guinea, } \\
\text { Ghana, Benin, and } \\
\text { Togo }\end{array}$ & $\begin{array}{l}\text { Women and } \\
\text { children }\end{array}$ & $\begin{array}{l}\text { Domestic } \\
\text { servitude, } \\
\text { sexual } \\
\text { exploitation and } \\
\text { farm labor }\end{array}$ & $\begin{array}{l}\text { Participant of } \\
\text { ILO trafficking } \\
\text { projects }\end{array}$ \\
\hline
\end{tabular}




\begin{tabular}{|c|c|c|c|c|c|}
\hline $\begin{array}{l}\text { Czech } \\
\text { Republic }\end{array}$ & $\begin{array}{l}\text { Source, } \\
\text { transit and } \\
\text { destination }\end{array}$ & $\begin{array}{l}\text { To Czech: from } \\
\text { Moldova, Romania, } \\
\text { Bulgaria, Ukraine, } \\
\text { Balkan countries } \\
\\
\text { From Czech: to } \\
\text { Western Europe } \\
\end{array}$ & $\begin{array}{l}\text { Women and } \\
\text { girls }\end{array}$ & $\begin{array}{l}\text { Sexual } \\
\text { exploitation }\end{array}$ & $\begin{array}{l}\text { There are } \\
\text { criminal codes } \\
\text { and statuses } \\
\text { that prohibit } \\
\text { trafficking in } \\
\text { women and } \\
\text { children }\end{array}$ \\
\hline $\begin{array}{l}\text { Dominican } \\
\text { Republic }\end{array}$ & Source & $\begin{array}{l}\text { Europe, Lesser } \\
\text { Antilles, Argentina, } \\
\text { Israel }\end{array}$ & $\begin{array}{l}\text { Primarily, } \\
\text { women and } \\
\text { in some } \\
\text { cases girls }\end{array}$ & $\begin{array}{l}\text { Sexual } \\
\text { exploitation }\end{array}$ & $\begin{array}{l}\text { Government is } \\
\text { making } \\
\text { significant } \\
\text { efforts to } \\
\text { combat it }\end{array}$ \\
\hline El Salvador & $\begin{array}{l}\text { Source and } \\
\text { transit }\end{array}$ & $\begin{array}{l}\text { Guatemala, and } \\
\text { other Central } \\
\text { American Countries }\end{array}$ & $\begin{array}{l}\text { Women and } \\
\text { girls }\end{array}$ & $\begin{array}{l}\text { Sexual } \\
\text { exploitation and } \\
\text { domestic } \\
\text { servitude }\end{array}$ & $\begin{array}{l}\text { Government } \\
\text { making } \\
\text { significant } \\
\text { effort to } \\
\text { combat it } \\
\end{array}$ \\
\hline Ethiopia & Source & Middle East & Women & $\begin{array}{l}\text { Domestic } \\
\text { servitude }\end{array}$ & $\begin{array}{l}\text { Penal code } \\
\text { sections that } \\
\text { criminalizes } \\
\text { trafficking, } \\
\text { enslavement } \\
\text { and abuse. } \\
\end{array}$ \\
\hline France & $\begin{array}{l}\text { Destination } \\
\text { and transit }\end{array}$ & $\begin{array}{l}\text { African, Southern } \\
\text { and Eastern Europe, } \\
\text { New Independent } \\
\text { States }\end{array}$ & Women & $\begin{array}{l}\text { Sexual } \\
\text { exploitation and } \\
\text { domestic } \\
\text { servitude }\end{array}$ & $\begin{array}{l}\text { Government } \\
\text { actively } \\
\text { investigates } \\
\text { and prosecutes } \\
\text { traffickers }\end{array}$ \\
\hline Georgia & $\begin{array}{l}\text { Source and } \\
\text { transit }\end{array}$ & $\begin{array}{l}\text { Turkey, Greece, } \\
\text { Israel, Western } \\
\text { Europe }\end{array}$ & $\begin{array}{l}\text { Women and } \\
\text { men }\end{array}$ & $\begin{array}{l}\text { Domestic } \\
\text { servitude and } \\
\text { sexual } \\
\text { exploitation } \\
\end{array}$ & $\begin{array}{l}\text { Government is } \\
\text { taking steps to } \\
\text { combat } \\
\text { trafficking }\end{array}$ \\
\hline Ghana & $\begin{array}{l}\text { Source, } \\
\text { transit and } \\
\text { destination }\end{array}$ & $\begin{array}{l}\text { To and from: Cote } \\
\text { D'Ivoire, Togo and } \\
\text { Nigeria } \\
\text { From: Burkina } \\
\text { Faso, } \\
\text { To: Europe and the } \\
\text { Middle East }\end{array}$ & $\begin{array}{l}\text { Women and } \\
\text { children }\end{array}$ & $\begin{array}{l}\text { Domestic } \\
\text { servitude, } \\
\text { sexual } \\
\text { exploitation, } \\
\text { farm labor }\end{array}$ & $\begin{array}{l}\text { No specific law } \\
\text { to prohibit and } \\
\text { prosecute } \\
\text { traffickers. } \\
\text { They could be } \\
\text { prosecuted } \\
\text { under laws } \\
\text { against slavery, } \\
\text { prostitution and } \\
\text { underage labor }\end{array}$ \\
\hline Guatemala & $\begin{array}{l}\text { Source and } \\
\text { transit }\end{array}$ & $\begin{array}{l}\text { Central America } \\
\text { and Canada }\end{array}$ & $\begin{array}{l}\text { Young } \\
\text { women and } \\
\text { children }\end{array}$ & $\begin{array}{l}\text { Sexual } \\
\text { exploitation }\end{array}$ & $\begin{array}{l}\text { Criminal codes } \\
\text { specifically } \\
\text { prohibits } \\
\text { trafficking }\end{array}$ \\
\hline
\end{tabular}




\begin{tabular}{|c|c|c|c|c|c|}
\hline Haiti & $\begin{array}{l}\text { Domestic } \\
\text { trafficking }\end{array}$ & & Children & $\begin{array}{l}\text { Prostitution and } \\
\text { domestic } \\
\text { servitude }\end{array}$ & $\begin{array}{l}\text { Poor children } \\
\text { may live with } \\
\text { and provide } \\
\text { domestic } \\
\text { services to } \\
\text { wealthier } \\
\text { families in } \\
\text { exchange for } \\
\text { sponsorship for } \\
\text { their education. } \\
\text { Government } \\
\text { has } \\
\text { acknowledged } \\
\text { internal } \\
\text { trafficking as a } \\
\text { problem and } \\
\text { making efforts } \\
\text { to combat it. }\end{array}$ \\
\hline Honduras & Source & $\begin{array}{l}\text { Neighboring } \\
\text { countries }\end{array}$ & Children & $\begin{array}{l}\text { Girls are used } \\
\text { for sexual } \\
\text { exploitation } \\
\text { while the boys } \\
\text { for drug } \\
\text { trafficking }\end{array}$ & $\begin{array}{l}\text { Criminal codes } \\
\text { exists against } \\
\text { trafficking in } \\
\text { persons }\end{array}$ \\
\hline Hungary & $\begin{array}{l}\text { Primarily } \\
\text { transit, and } \\
\text { also source } \\
\text { and } \\
\text { destination }\end{array}$ & $\begin{array}{l}\text { To Hungary: from } \\
\text { Romania, Ukraine, } \\
\text { Moldova, Poland, } \\
\text { Yugoslavia and } \\
\text { China } \\
\text { From Hungary: to } \\
\text { Pakistan, Iraq, } \\
\text { Bangladesh, and } \\
\text { Afghanistan }\end{array}$ & $\begin{array}{l}\text { Women, } \\
\text { men and } \\
\text { children }\end{array}$ & $\begin{array}{l}\text { Men trafficked } \\
\text { for purposes of } \\
\text { forced labor, } \\
\text { women and } \\
\text { children are for } \\
\text { sexual } \\
\text { exploitation }\end{array}$ & $\begin{array}{l}\text { A trafficking } \\
\text { law provides } \\
\text { for penalties } \\
\text { similar to those } \\
\text { for rape. } \\
\text { Government } \\
\text { making efforts } \\
\text { to combat } \\
\text { trafficking }\end{array}$ \\
\hline India & $\begin{array}{l}\text { Source, } \\
\text { transit, } \\
\text { destination }\end{array}$ & $\begin{array}{l}\text { To India: from } \\
\text { Bangladesh, Nepal } \\
\text { From India: to other } \\
\text { countries in Asia, } \\
\text { Middle East }\end{array}$ & $\begin{array}{l}\text { Women, and } \\
\text { children }\end{array}$ & $\begin{array}{l}\text { Sexual } \\
\text { exploitation, } \\
\text { forced labor }\end{array}$ & $\begin{array}{l}\text { There is } \\
\text { widespread } \\
\text { internal } \\
\text { trafficking. } \\
\text { Government is } \\
\text { unable to } \\
\text { implement } \\
\text { plans for } \\
\text { combating } \\
\text { trafficking } \\
\text { because of } \\
\text { resource } \\
\text { constraint. }\end{array}$ \\
\hline
\end{tabular}




\begin{tabular}{|c|c|c|c|c|c|}
\hline Japan & Destination & $\begin{array}{l}\text { Thailand, the } \\
\text { Philippines, and the } \\
\text { New Independent } \\
\text { States }\end{array}$ & Women & $\begin{array}{l}\text { Sexual } \\
\text { exploitation }\end{array}$ & $\begin{array}{l}\text { There are no } \\
\text { loaws that } \\
\text { prohibit } \\
\text { trafficking in } \\
\text { persons but } \\
\text { government } \\
\text { making efforts } \\
\text { to combat it. }\end{array}$ \\
\hline Kyrgyzstan & $\begin{array}{l}\text { Source and } \\
\text { transit }\end{array}$ & $\begin{array}{l}\text { To: Women are } \\
\text { trafficked to Russia, } \\
\text { Turkey, Germany, } \\
\text { and the united Arab, } \\
\text { Emirates, while the } \\
\text { men to Kazakhstan }\end{array}$ & $\begin{array}{l}\text { Women, } \\
\text { men and } \\
\text { children }\end{array}$ & $\begin{array}{l}\text { Women and } \\
\text { children are } \\
\text { forced into } \\
\text { prostitution } \\
\text { while the men } \\
\text { provide forced } \\
\text { labor } \\
\end{array}$ & $\begin{array}{l}\text { The } \\
\text { government is } \\
\text { about to } \\
\text { implement a } \\
13 \text {-step plan to } \\
\text { combat } \\
\text { trafficking }\end{array}$ \\
\hline Laos & Source & Thailand and China & $\begin{array}{l}\text { Young } \\
\text { women and } \\
\text { men }\end{array}$ & $\begin{array}{l}\text { Sexual } \\
\text { exploitation and } \\
\text { labor for } \\
\text { sweatshops }\end{array}$ & $\begin{array}{l}\text { Government } \\
\text { devotes funds } \\
\text { for combating } \\
\text { and has set up a } \\
\text { team in the } \\
\text { Ministry of } \\
\text { Labor and } \\
\text { Social Welfare } \\
\text { to protect } \\
\text { children }\end{array}$ \\
\hline Lithuania & $\begin{array}{l}\text { Source, } \\
\text { transit and } \\
\text { destination } \\
\text { country }\end{array}$ & $\begin{array}{l}\text { To Western Europe, } \\
\text { and the Middle East }\end{array}$ & Women & $\begin{array}{l}\text { Sexual } \\
\text { exploitation }\end{array}$ & $\begin{array}{l}\text { Government } \\
\text { making efforts } \\
\text { to combat } \\
\text { trafficking, } \\
\text { there is a } \\
\text { criminal code } \\
\text { that prohibits } \\
\text { trafficking }\end{array}$ \\
\hline Macedonia & $\begin{array}{l}\text { Transit and } \\
\text { destination }\end{array}$ & $\begin{array}{l}\text { To Macedonia: from } \\
\text { Ukraine, Moldova, } \\
\text { Romania, Bulgaria. } \\
\text { Transit to: Italy, } \\
\text { Albania and Kosovo }\end{array}$ & $\begin{array}{l}\text { Women } \\
\text { mostly }\end{array}$ & $\begin{array}{l}\text { Sexual } \\
\text { exploitation }\end{array}$ & $\begin{array}{l}\text { Laws don't } \\
\text { specifically } \\
\text { prohibit } \\
\text { trafficking but } \\
\text { traffickers } \\
\text { could be tried } \\
\text { under laws } \\
\text { prohibiting } \\
\text { slavery, } \\
\text { kidnapping, } \\
\text { illegal entry } \\
\text { etc. }\end{array}$ \\
\hline Mali & $\begin{array}{l}\text { Source and } \\
\text { destination }\end{array}$ & $\begin{array}{l}\text { From Mali: to Cote } \\
\text { D'Ivoire, } \\
\text { To Mali: from } \\
\text { Nigeria }\end{array}$ & Children & $\begin{array}{l}\text { Farm labor, } \\
\text { domestic } \\
\text { servitude and } \\
\text { sexual } \\
\text { exploitation } \\
\end{array}$ & $\begin{array}{l}\text { Government } \\
\text { making efforts } \\
\text { to combat it }\end{array}$ \\
\hline
\end{tabular}




\begin{tabular}{|c|c|c|c|c|c|}
\hline Mexico & $\begin{array}{l}\text { Source and } \\
\text { transit }\end{array}$ & $\begin{array}{l}\text { From Macedonia: to } \\
\text { US, Canada, Japan } \\
\text { Transit from China } \\
\text { and Central } \\
\text { America } \\
\end{array}$ & $\begin{array}{l}\text { Include } \\
\text { children (rest } \\
\text { not } \\
\text { specified) }\end{array}$ & $\begin{array}{l}\text { Sexual } \\
\text { exploitation }\end{array}$ & $\begin{array}{l}\text { No specific } \\
\text { laws to prohibit } \\
\text { trafficking but } \\
\text { other laws } \\
\text { could be used } \\
\end{array}$ \\
\hline Moldova & $\begin{array}{l}\text { Source and } \\
\text { transit }\end{array}$ & $\begin{array}{l}\text { To: Turkey, the } \\
\text { Balkan Region, } \\
\text { Italy and Greece }\end{array}$ & $\begin{array}{l}\text { Women and } \\
\text { girls }\end{array}$ & Not specified & $\begin{array}{l}\text { Government } \\
\text { taking steps to } \\
\text { combat it }\end{array}$ \\
\hline Morocco & $\begin{array}{l}\text { Source and } \\
\text { transit } \\
\text { country }\end{array}$ & $\begin{array}{l}\text { To: Middle East, } \\
\text { and Europe }\end{array}$ & $\begin{array}{l}\text { Women and } \\
\text { girls }\end{array}$ & $\begin{array}{l}\text { Sexual } \\
\text { exploitation and } \\
\text { domestic } \\
\text { servitude } \\
\text { internally } \\
\end{array}$ & $\begin{array}{l}\text { Government } \\
\text { making efforts } \\
\text { to combat it }\end{array}$ \\
\hline Nepal & Source & $\begin{array}{l}\text { Hong Kong, } \\
\text { Thailand, India and } \\
\text { the Middle East }\end{array}$ & $\begin{array}{l}\text { Women and } \\
\text { children }\end{array}$ & $\begin{array}{l}\text { Prostitution and } \\
\text { bonded labor }\end{array}$ & $\begin{array}{l}\text { Human } \\
\text { Trafficking Act } \\
\text { (1986) } \\
\text { prohibits } \\
\text { selling persons } \\
\text { in Nepal or } \\
\text { abroad. } \\
\end{array}$ \\
\hline Nigeria & $\begin{array}{l}\text { Source, } \\
\text { transit and } \\
\text { destination }\end{array}$ & $\begin{array}{l}\text { From Nigeria: to } \\
\text { Europe, other } \\
\text { African countries, }\end{array}$ & $\begin{array}{l}\text { Women and } \\
\text { children }\end{array}$ & $\begin{array}{l}\text { Prostitution ad } \\
\text { farm labor }\end{array}$ & $\begin{array}{l}\text { Government } \\
\text { implemented } \\
\text { revised anti- } \\
\text { trafficking } \\
\text { criminal } \\
\text { statutes in } \\
1998 \text {. Penalties } \\
\text { of up to } 10 \\
\text { years } \\
\text { imprisonment }\end{array}$ \\
\hline Sierra Leone & $\begin{array}{l}\text { Internal } \\
\text { trafficking }\end{array}$ & & $\begin{array}{l}\text { Men, women } \\
\text { and children }\end{array}$ & $\begin{array}{l}\text { Forced labor, } \\
\text { sexual servitude } \\
\text { and forced } \\
\text { military } \\
\text { conscription }\end{array}$ & $\begin{array}{l}\text { RUF rebels are } \\
\text { responsible for } \\
\text { these } \\
\text { abductions }\end{array}$ \\
\hline Singapore & Destination & $\begin{array}{l}\text { From Thailand, } \\
\text { China, Sri Lank, } \\
\text { India, Bangladesh } \\
\text { and the Philippines }\end{array}$ & $\begin{array}{l}\text { Women and } \\
\text { men }\end{array}$ & $\begin{array}{l}\text { Sexual } \\
\text { exploitation }\end{array}$ & $\begin{array}{l}\text { This is the only } \\
\text { country that } \\
\text { meets standards } \\
\text { against } \\
\text { trafficking }\end{array}$ \\
\hline Slovenia & $\begin{array}{l}\text { Transit and } \\
\text { destination }\end{array}$ & $\begin{array}{l}\text { From: Ukraine, } \\
\text { Czech, Slovakia, } \\
\text { Moldova, Russia, } \\
\text { Romania and } \\
\text { Bulgaria through } \\
\text { Slovenia to Italy, } \\
\text { Belgium and the } \\
\text { Netherlands } \\
\end{array}$ & $\begin{array}{l}\text { Mostly } \\
\text { women }\end{array}$ & \begin{tabular}{|l} 
Sexual \\
exploitation
\end{tabular} & $\begin{array}{l}\text { Government is } \\
\text { making effort } \\
\text { to combat it }\end{array}$ \\
\hline
\end{tabular}




\begin{tabular}{|c|c|c|c|c|c|}
\hline South Africa & $\begin{array}{l}\text { Destination, } \\
\text { transit and } \\
\text { internal } \\
\text { trafficking }\end{array}$ & $\begin{array}{l}\text { Other African } \\
\text { countries, Asia, } \\
\text { Eastern Europe, } \\
\text { Russia and the New } \\
\text { Independent States. } \\
\text { Transit to Europe, } \\
\text { US and Canada }\end{array}$ & Women & Not specified & $\begin{array}{l}\text { Government's } \\
\text { efforts at } \\
\text { combating } \\
\text { trafficking tend } \\
\text { to be thwarted } \\
\text { by corruption } \\
\text { and lack of } \\
\text { resources }\end{array}$ \\
\hline Sri Lanka & $\begin{array}{l}\text { Source and } \\
\text { destination }\end{array}$ & $\begin{array}{l}\text { From S. Lanka: to } \\
\text { the Middle East, } \\
\text { To S. Lanka: from } \\
\text { China and Thailand }\end{array}$ & $\begin{array}{l}\text { Women and } \\
\text { children }\end{array}$ & $\begin{array}{l}\text { Boys work as } \\
\text { camel jockeys, } \\
\text { women are } \\
\text { forced into } \\
\text { domestic } \\
\text { servitude and } \\
\text { prostitution }\end{array}$ & $\begin{array}{l}\text { Liberation } \\
\text { Tigers of Tamil } \\
\text { Eelam abduct } \\
\text { and hold } \\
\text { children against } \\
\text { their will for } \\
\text { the purposes of } \\
\text { forced labor } \\
\text { and military } \\
\text { conscription }\end{array}$ \\
\hline Sweden & Destination & $\begin{array}{l}\text { Baltic States, } \\
\text { Central and Eastern } \\
\text { Europe, Cuba and } \\
\text { Colombia }\end{array}$ & Women & $\begin{array}{l}\text { Sexual } \\
\text { exploitation }\end{array}$ & $\begin{array}{l}\text { Government } \\
\text { making } \\
\text { significant } \\
\text { effort to } \\
\text { combat } \\
\text { trafficking } \\
\end{array}$ \\
\hline Thailand & $\begin{array}{l}\text { Destination, } \\
\text { source and } \\
\text { transit }\end{array}$ & $\begin{array}{l}\text { To Thailand from: } \\
\text { Burma, Laos and } \\
\text { Cambodia } \\
\text { From Thailand to } \\
\text { Japan, Taiwan, } \\
\text { Australia, Europe } \\
\text { and the US. }\end{array}$ & $\begin{array}{l}\text { Women and } \\
\text { girls }\end{array}$ & $\begin{array}{l}\text { Sexual } \\
\text { exploitation, } \\
\text { farm, farm, } \\
\text { industrial and } \\
\text { domestic labor }\end{array}$ & $\begin{array}{l}\text { Government is } \\
\text { making } \\
\text { significant } \\
\text { efforts to } \\
\text { combat it }\end{array}$ \\
\hline Togo & $\begin{array}{l}\text { Source and } \\
\text { transit }\end{array}$ & $\begin{array}{l}\text { From Togo: to Cote } \\
\text { D'Ivoire, Gabon, } \\
\text { Nigeria, Middle Eat } \\
\text { and Europe } \\
\text { Transit: from } \\
\text { Ghana, Burkina } \\
\text { Faso, Cote D'Ivoire } \\
\text { and Nigeria }\end{array}$ & $\begin{array}{l}\text { Mostly } \\
\text { children }\end{array}$ & $\begin{array}{l}\text { Domestic } \\
\text { servitude, farm } \\
\text { labor, and } \\
\text { sexual } \\
\text { exploitation }\end{array}$ & $\begin{array}{l}\text { Government is } \\
\text { making efforts } \\
\text { to combat } \\
\text { trafficking }\end{array}$ \\
\hline Uganda & Source & & $\begin{array}{l}\text { Women and } \\
\text { children }\end{array}$ & $\begin{array}{l}\text { Sex slaves and } \\
\text { labor }\end{array}$ & $\begin{array}{l}\text { Lord's } \\
\text { Resistance } \\
\text { Army (LRA) } \\
\text { kidnapped } \\
5,100 \text { Ugandan, } \\
\text { Congolese and } \\
\text { Sudanese } \\
\text { children in the } \\
\text { past } 10 \text { years } \\
\text { and forced } \\
\text { them to become } \\
\text { soldiers } \\
\end{array}$ \\
\hline
\end{tabular}




\begin{tabular}{|l|l|l|l|l|l|}
\hline Ukraine & $\begin{array}{l}\text { Source and } \\
\text { transit }\end{array}$ & $\begin{array}{l}\text { To: Central and } \\
\text { Western Europe, US } \\
\text { and Middle East }\end{array}$ & $\begin{array}{l}\text { Women and } \\
\text { girls }\end{array}$ & $\begin{array}{l}\text { Sexual } \\
\text { exploitation }\end{array}$ & $\begin{array}{l}\text { Government } \\
\text { has increased } \\
\text { efforts to } \\
\text { combat } \\
\text { trafficking in } \\
\text { persons but is } \\
\text { faced with } \\
\text { problems of } \\
\text { corruption and } \\
\text { lack of } \\
\text { resources. }\end{array}$ \\
\hline Vietnam & $\begin{array}{l}\text { Source ad } \\
\text { transit }\end{array}$ & $\begin{array}{l}\text { From Vietnam: to } \\
\text { other arts of Asia } \\
\text { and elsewhere } \\
\text { To Vietnam: from } \\
\text { China and } \\
\text { Cambodia }\end{array}$ & Women & $\begin{array}{l}\text { Sexual } \\
\text { exploitation and } \\
\text { arranged } \\
\text { marriages }\end{array}$ & $\begin{array}{l}\text { Corruption is a } \\
\text { serious } \\
\text { problem that } \\
\text { affects } \\
\text { government's } \\
\text { efforts at } \\
\text { combating } \\
\text { trafficking in } \\
\text { persons. }\end{array}$ \\
\hline
\end{tabular}

